medRxiv preprint doi: https://doi.org/10.1101/2020.05.14.20094821; this version posted May 18, 2020. The copyright holder for this preprint (which was not certified by peer review) is the author/funder, who has granted medRxiv a license to display the preprint in perpetuity.

It is made available under a CC-BY-NC 4.0 International license.

\title{
Transmission of aerosols through pristine and reprocessed N95 respirators
}

3 Paul Z. Chen, B.ASc. ${ }^{1}$, Aldrich Ngan, M.ASc. ${ }^{1}$, Niclas Manson, M.P.H. ${ }^{2}$, Jason T. Maynes,

4 M.D., Ph.D. ${ }^{2}$, Gregory H. Borschel, M.D. ${ }^{2}$, Ori D. Rotstein, M.D. ${ }^{3}$, Frank X. Gu, Ph.D. ${ }^{1, *}$

$6 \quad{ }^{1}$ University of Toronto, Toronto, ON, Canada

$7 \quad{ }^{2}$ Hospital for Sick Children, Toronto, ON, Canada

$8 \quad{ }^{3}$ St. Michael's Hospital, Toronto, ON, Canada

*Correspondence author: f.gu@utoronto.ca

\section{Abstract}

13 During the Covid-19 pandemic, pristine and reprocessed N95 respirators are crucial equipment

14 towards limiting nosocomial infections. The NIOSH test certifying the N95 rating, however,

15 poorly simulates aerosols in healthcare settings, limiting our understanding of the exposure risk

16 for healthcare workers wearing these masks, especially reprocessed ones. We used experimental

17 conditions that simulated the sizes, densities and airflow properties of infectious aerosols in

18 healthcare settings. We analyzed the penetration and leakage of aerosols through pristine and

19 reprocessed N95 respirators. Seven reprocessing methods were investigated. Our findings

20 suggest that pristine and properly reprocessed N95 respirators effectively limit exposure to

21 infectious aerosols, but that care must be taken to avoid the elucidated degradation mechanisms

22 and limit noncompliant wear. 
medRxiv preprint doi: https://doi.org/10.1101/2020.05.14.20094821; this version posted May 18, 2020. The copyright holder for this preprint (which was not certified by peer review) is the author/funder, who has granted medRxiv a license to display the preprint in perpetuity.

It is made available under a CC-BY-NC 4.0 International license .

23 During the Covid-19 pandemic, disposable N95 filtering facepiece respirators (N95 FFRs) are

24 crucial equipment towards limiting nosocomial infections. ${ }^{1}$ To address critical shortages,

25 reprocessing is being implemented to facilitate their limited reuse. ${ }^{2}$ The N95 rating suggests that

26 up to $5 \%$ of airborne particles may transmit through an N95 FFR. The NIOSH tests certifying

27 this rating, however, poorly simulate the transmission of aerosols in healthcare settings, ${ }^{3}$ limiting

28 our understanding of the exposure risk for healthcare workers performing aerosol-generating

29 medical procedures and of the implications of reprocessing.

We analyzed the penetration (transmission through the filter media) and leakage

31 (transmission around imperfections in facial seal) of aerosols into pristine and reprocessed N95

32 FFRs. We examined three prevalent healthcare models (3M 1860S, 3M 8210 and 3M 9210) and

33 reprocessed them $(1,3,5$ or 10 cycles $)$ using seven methods under consideration for

34 implementation in hospitals: autoclave, 70\% ethanol vapor (vEtOH), forced-air dry heat (100

$\left.35{ }^{\circ} \mathrm{C}\right)$, humid heat $\left(75 \%\right.$ relative humidity, $\left.75^{\circ} \mathrm{C}\right)$, hydrogen peroxide gas plasma (HPGP,

36 STERRAD® 100S), hydrogen peroxide vapor (HPV, STERIS V-PRO®) and ultraviolet

37 germicidal irradiation (UVGI). Leakage was assessed via fit testing. Penetration was evaluated

38 using a polydisperse challenge aerosol $\left(0.1\right.$ to $1 \mu \mathrm{m}$; material density, $\left.1.05 \mathrm{~g} / \mathrm{cm}^{3}\right)$ and conditions

39 that simulated the sizes, densities and airflow properties of infectious aerosols in healthcare

40 settings (see the Supplementary Appendix for the Experimental design and Methods sections). ${ }^{4}$

$41 \quad$ For both pristine (Fig. 1A) and reprocessed (Fig. S1 to S7) N95 FFRs, penetration rapidly

42 decreased as aerosol size increased according to a power relationship. Power regression verified

43 this trend, with a cumulative $R^{2}$ of $0.94 \pm 0.041$ for all penetration experiments in this study $(N=$

44 72). For pristine N95 FFRs, the expected aerosol penetration was between $0.09 \%$ and $0.19 \%$ at

$450.1 \mu \mathrm{m}, 0.02 \%$ and $0.03 \%$ at $0.3 \mu \mathrm{m}$ and at the detection limit, $0.01 \%$, above $0.5 \mu \mathrm{m}$ (Fig. $1 \mathrm{~A})$. 
medRxiv preprint doi: https://doi.org/10.1101/2020.05.14.20094821; this version posted May 18, 2020. The copyright holder for this preprint (which was not certified by peer review) is the author/funder, who has granted medRxiv a license to display the preprint in perpetuity.

It is made available under a CC-BY-NC 4.0 International license .

When properly fitted, we measured aerosol leakage at the detection limit, $0.49 \%$, for the

three N95 models (Fig. 1B). As such, the estimated overall transmission (sum of penetration and leakage) was $\leq 0.68 \%$, with the most penetrating particle size at $0.1 \mu \mathrm{m}$. Improper wear due to a

49 pinched nose clip, a common issue, significantly enhanced leakage (Fig. 1C).

Reprocessing methods varied in their effects on aerosol transmission (Fig. 1D). At $0.3 \mu \mathrm{m}$,

51 HPV kept overall transmission below $1.5 \%$ up to 10 cycles, while force-air dry heat and humid

52 heat did so up to 3 cycles. HPGP and UVGI did for 1 cycle but increased transmission by the

53 third cycle; samples reprocessed twice were not included in this study. These five methods kept

54 leakage below $0.6 \%$ for the identified cycles. Autoclave physically deformed the pleated models

55 (3M 1860S and 3M 8210), inducing leakage; the molded model (3M 9210) was unaffected.

56 UVGI induced slight dose-dependent photochemical damage (Fig. S8). HPGP caused leakage

57 around the nose by 5 cycles: reactive oxygen species generated during the plasma phase

58 progressively embrittled and degraded polyurethane nose foams across N95 models (Fig. S9 and

59 S10). For mechanistic insight into how reprocessing increased penetration, we measured the

60 pressure differential, which indicates structural changes, across each FFR. N95 filter media

61 collect aerosols based on their static charge or structure. Pressure differentials stayed consistent

62 (Table S1), implying the seven methods increased penetration mainly by degrading filter charge.

63 Equivalence testing demonstrated that N95 FFRs reprocessed once using forced-air dry heat,

64 HPGP or HPV were statistically equivalent to pristine ones in terms of aerosol transmission (Fig.

$651 \mathrm{E}$ and $\mathrm{S} 11, P<0.01$ or $P<0.001)$, subverting the conventional expectation that the very act of

66 reprocessing increases transmission. No N95 FFRs showed equivalency up to 3 cycles (Fig. 1F

67 and $\mathrm{S} 12, P>0.05)$. 
Our findings help better understand aerosol exposure for healthcare workers wearing N95

69 FFRs. Since the size of SARS-CoV-2 and influenza virions is approximately $0.1 \mu \mathrm{m},{ }^{5}$ infectious

70 aerosols containing them are larger than $0.1 \mu \mathrm{m}$. Our results suggest that $<0.68 \%$ of these virus-

71 containing aerosols transmit into a pristine N95 FFR. Our data indicates HPV, forced-air dry

72 heat, humid heat, HPGP and UVGI maintain $<1.5 \%$ transmission at $0.3 \mu \mathrm{m}$, and in some cases

73 preserve pristine performance, within the identified cycle numbers. The established power

74 relationship demonstrates penetration decreases considerably as aerosol size increases. In

75 comparison, improper wear induces significant leakage, highlighting the importance of

76 compliant wear. These findings suggest pristine and properly reprocessed N95 FFRs effectively

77 protect against infectious aerosols, but that care must be taken during use and reprocessing to

78 mitigate degradation of filter charge, avoid deterioration of straps and nose foams, preserve mask

79 shape especially for molded models and limit noncompliant wear. 
A Penetration plots (pristine N95 FFRs)
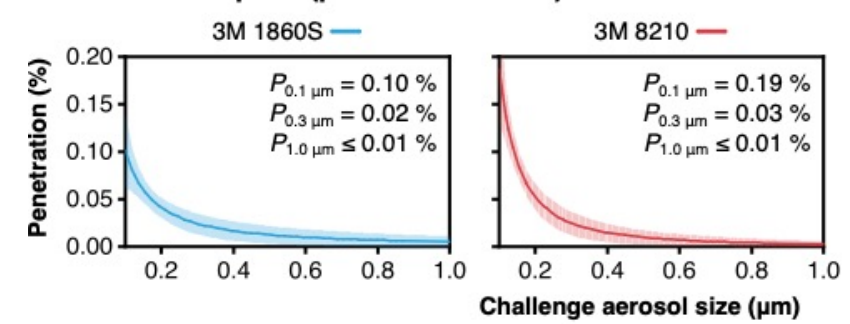

$3 \mathrm{M} 9210-$

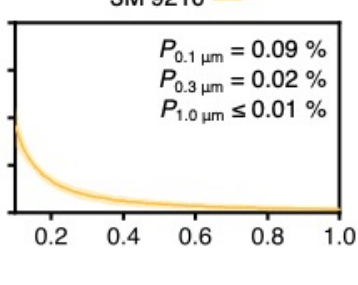

B Leakage (pristine)

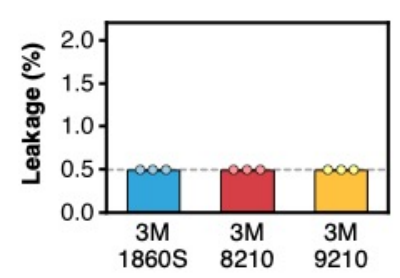

C Leakage (pinched nose)

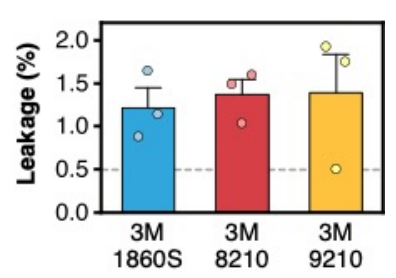

D Overall transmission and leakage for reprocessed N95 FFRs (at $0.3 \mu \mathrm{m}$ )
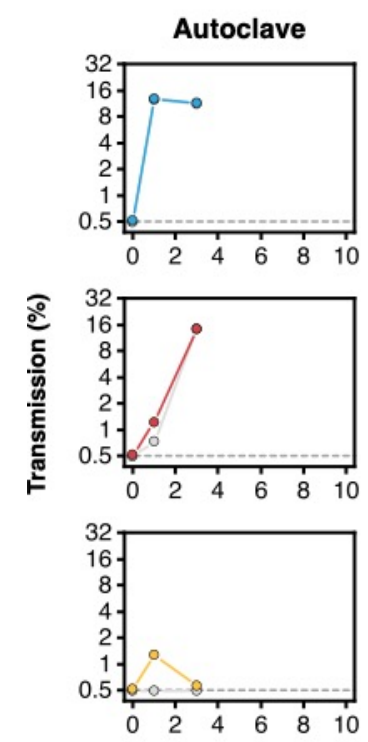

vEtOH

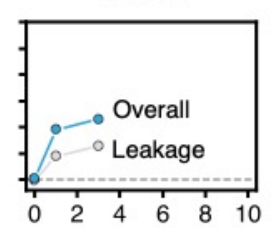

Forced-air dry heat
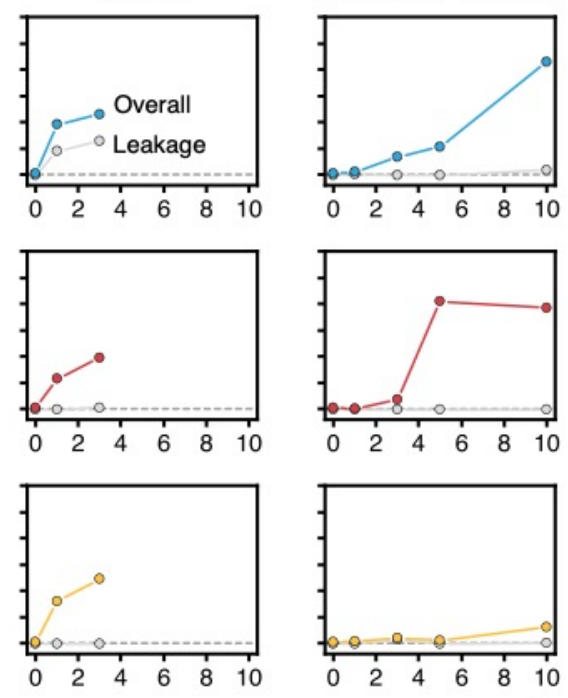

Overall (3M 1860S) - 0
Humid heat

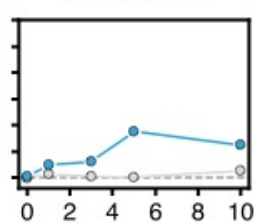

HPGP
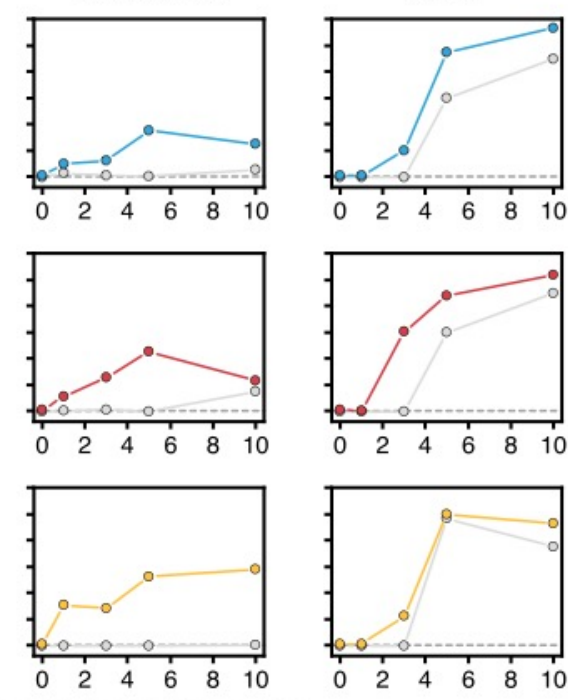

HPV
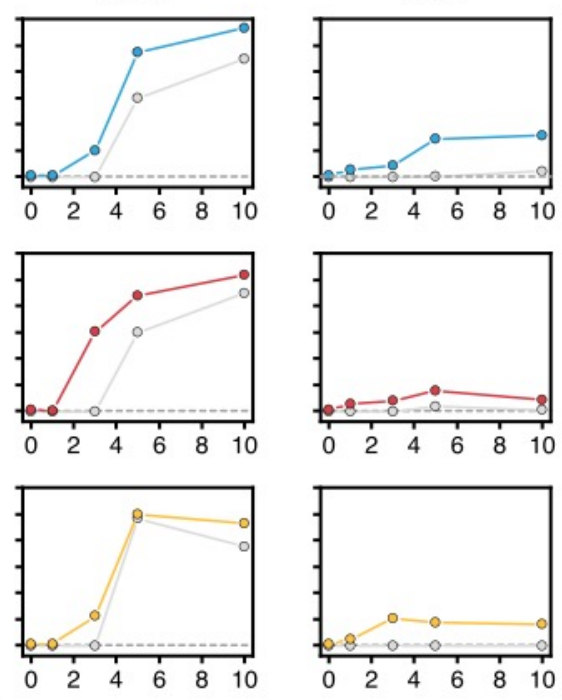

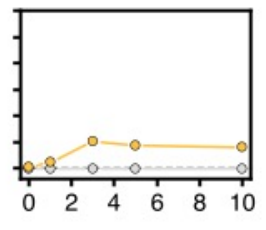

Leakage $\circ$

UVGI
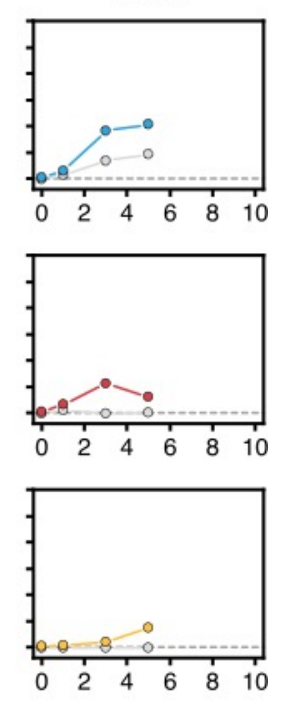

E Overall transmission (1 cycle for reprocessed N95 FFRs, at $0.3 \mu \mathrm{m}$ )

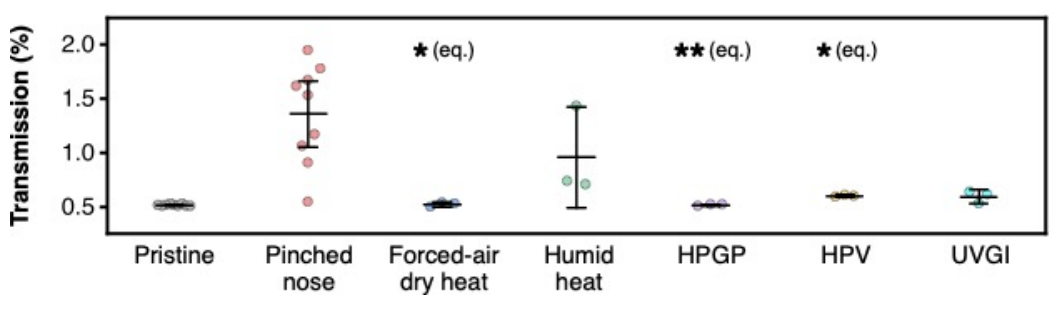

F Overall transmission (up to 3 cycles for reprocessed N95 FFRs, at $0.3 \mu \mathrm{m}$ )

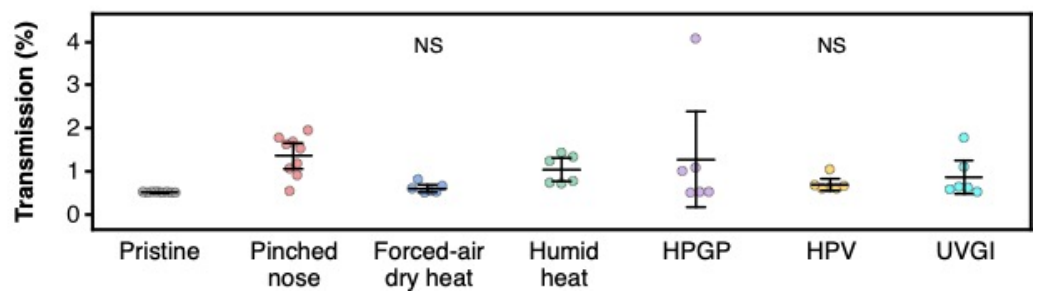


medRxiv preprint doi: https://doi.org/10.1101/2020.05.14.20094821; this version posted May 18, 2020. The copyright holder for this preprint (which was not certified by peer review) is the author/funder, who has granted medRxiv a license to display the preprint in perpetuity.

It is made available under a CC-BY-NC 4.0 International license.

\section{Figure 1. Penetration, leakage and overall transmission of aerosols into pristine and}

82 reprocessed N95 FFRs. (A) Aerosol penetration was measured using three models of pristine

83 N95 FFRs. A polydisperse challenge aerosol $\left(0.1\right.$ to $1.0 \mu \mathrm{m}$, material density of $\left.1.05 \mathrm{~g} / \mathrm{cm}^{3}\right)$ was

84 introduced at $1.0 \mathrm{scfm}$ while experimental conditions were maintained at $20.9 \pm 0.52{ }^{\circ} \mathrm{C}$ and 48.5

$85 \pm 3.70 \%$ RH. Power regression was performed on discrete measurements. Plots show the size-

86 dependent expectation curves and the $95 \%$ confidence intervals of individual samples. The inset

87 values represent the expected penetration at $0.1,0.3$ and $1.0 \mu \mathrm{m}$. The detection limit was $0.01 \%$

88 across aerosol sizes. (B and $\mathbf{C}$ ) Aerosol leakage was quantified into three models of pristine N95

89 FFRs worn properly (B) or with a pinched nose clip (C). Graphs show size-independent means

90 and their standard errors. The dashed lines indicate the detection limit, which was 0.49\%. (D)

91 The three models of N95 FFRs were reprocessed for 1, 3, 5 or 10 cycles and characterized for

92 penetration and leakage while worn properly. We only implemented autoclave and vEtOH up to

933 cycles; and UVGI up to 5 cycles. Plots show the overall aerosol transmission, the sum of the

94 expected penetration and leakage, at $0.3 \mu \mathrm{m}$ and leakage over cycle numbers. The dashed lines

95 indicate the detection limit for overall transmission, which was $0.50 \%$. (E and F) Pristine N95

96 FFRs were compared with ones reprocessed up to 1 cycle (E) or 3 cycles (F). Plots show the

97 individual data points, means and 95\% confidence intervals for overall aerosol transmission at

$98 \quad 0.3 \mu \mathrm{m}$. Data across N95 models were grouped together up to each cycle number. Autoclave and

99 vEtOH were excluded from these plots and reported in the Supplementary Appendix.

100 Equivalence testing compared reprocessed N95 FFRs with pristine ones. ${ }^{*} P<0.01,{ }^{*} P<0.001$;

101 NS, non-significant $(P>0.05)$. 
medRxiv preprint doi: https://doi.org/10.1101/2020.05.14.20094821; this version posted May 18, 2020. The copyright holder for this preprint (which was not certified by peer review) is the author/funder, who has granted medRxiv a license to display the preprint in perpetuity.

It is made available under a CC-BY-NC 4.0 International license.

\section{References}

103 1. Rational use of personal protective equipment for coronavirus disease (COVID-19) and

104 considerations during severe shortages: Interim guidance, 6 April 2020. Geneva: World

105 Health Organization, 2020 (https://apps.who.int/iris/handle/10665/331695).

106 2. Enforcement policy for face masks and respirators during the coronavirus disease (Covid-

107 19) public health emergency (revised): Guidance for industry and Food and Drug

108 Administration staff (FDA-2020-D-1138). Silver Spring, MD: U.S. Food and Drug

109 Administration, April 2, 2020 (https:/www.fda.gov/media/136449/download).

110 3. 42 CFR 84 - Approval of respiratory protective devices. Washington, DC: National

111 Institute for Occupational Safety and Health, October 1, 2010

112 (https:/www.govinfo.gov/content/pkg/CFR-2010-title42-vol1/pdf/CFR-2010-title42-vol1-

113 part84.pdf).

114 4. van Doremalen N, Bushmaker T, Morris DH, et al. Aerosol and surface stability of SARS-

115 CoV-2 as compared with SARS-CoV-1. N Engl J Med 2020;382:1564-7.

116 5. Zhu N, Zhang D, Wang W, et al. A novel coronavirus from patients with pneumonia in

117 China, 2019. N Engl J Med 2020;382:727-33. 
medRxiv preprint doi: https://doi.org/10.1101/2020.05.14.20094821; this version posted May 18, 2020. The copyright holder for this preprint (which was not certified by peer review) is the author/funder, who has granted medRxiv a license to display the preprint in perpetuity.

It is made available under a CC-BY-NC 4.0 International license.

Supplementary Appendix

123 Table of Contents

124 Experimental design

page 9

125 Methods

page 12

126 Limitations of this study

page 21

127 Supplementary figures

page 23

128 Supplementary table

page 36

129 Author contributions

page 38

130 Acknowledgements

page 38

131 Supplementary references

page 38 
medRxiv preprint doi: https://doi.org/10.1101/2020.05.14.20094821; this version posted May 18, 2020. The copyright holder for this preprint (which was not certified by peer review) is the author/funder, who has granted medRxiv a license to display the preprint in perpetuity.

It is made available under a CC-BY-NC 4.0 International license.

\section{Experimental design}

We designed this study to better understand how aerosols relevant to nosocomial infections

134 transmit through N95 FFRs. The N95 rating means that the FFR filter is not resistant to oil and

135 that a minimum of $95 \%$ of airborne particles are filtered while fitted properly. We chose not to

136 use the NIOSH certification tests (42 CFR Part 84, TEB-APR-STP-0059 protocol) for our

137 study. ${ }^{3,6}$ This protocol characterizes filtration efficiency by using relatively monodisperse $75-\mathrm{nm}$

$138 \mathrm{NaCl}$ particles (material density, $2.16 \mathrm{~g} / \mathrm{cm}^{3}$ ), using specific humidity conditions

139 (preconditioning at $85 \%$ relative humidity and $38{ }^{\circ} \mathrm{C}$ for $24 \mathrm{~h}$ ) and loading particulate matter up

140 to the mass threshold $(200 \mathrm{mg})$ under increased flow rates $(85 \mathrm{~L} / \mathrm{min}) .{ }^{6}$ In healthcare

141 environments, it is not expected for N95 FFRs to uptake particulates up to the loading threshold. ${ }^{7}$

142 Moreover, as explained below, the particulates and conditions used in this testing protocol are

143 dissimilar to the aerosols and conditions of interest for this study.

144 The airflow and transmission characteristics of aerosols depend on the physicochemical

145 properties of the aerosol and the properties of the surrounding gas. Description of the motion of

146 spherical aerosols can be formalized by the Maxey and Riley differential force balance, the

147 relative Reynolds number (Re), Stokes' law and a statistical treatment of Brownian motion. ${ }^{8-11}$

148 The differential force equation can be written in the $x$-direction in Cartesian coordinates as

$$
\frac{d u_{a}}{d t}=F_{D}\left(u-u_{a}\right)+\frac{g_{x}\left(\rho_{a}-\rho\right)}{\rho_{a}}+F_{x},
$$

150 where $u_{a}$ is the aerosol particle velocity, $t$ is time, $F_{D}\left(u-u_{a}\right)$ is the drag force per unit particle

151 mass, $\rho_{a}$ is the aerosol particle material density, $\rho$ is the fluid (in our case, gas) material density

152 and $F_{x}$ accounts for additional forces acting on the system. The relative Reynolds number is

153 defined as 


$$
\operatorname{Re}=\frac{\rho D_{a}\left|u_{a}-u\right|}{\mu},
$$

155 where $D_{a}$ is the aerosol particle diameter, $u$ is the fluid velocity and $\mu$ is the dynamic viscosity of 156 the fluid. For submicron aerosol particles, Stokes' law describes

$$
F_{D}=\frac{18 \mu}{D_{a}^{2} \rho_{a} C_{c}},
$$

where the Cunningham correction factor is defined as

$$
C_{c}=1+\frac{2 \lambda}{D_{a}}\left\{1.257+0.4 \exp \left[-1.1\left(\frac{D_{a}}{2 \lambda}\right)\right]\right\}
$$

161 required to accelerate the fluid surrounding the particle and due to a pressure gradient in the

162 fluid, the additional force term in eq. (1) can written as

$$
F_{x}=\frac{1}{2} \frac{\rho}{\rho_{a}} \frac{d}{d t}\left(u-u_{a}\right)+\frac{\rho}{\rho_{a}} u_{a} \frac{d u}{d x} .
$$
well. The amplitudes of the Brownian forces components are described by

$$
F_{b, i}=\zeta_{i} \sqrt{\frac{\pi S_{0}}{\Delta t}}
$$

167 where $\zeta_{i}$ are zero-mean, unit-variance-independent Gaussian random numbers at time step $i$. The

168 components of the Brownian forces can be modeled as a Gaussian white noise process with

169 spectra intensity $S_{i j}^{n}$ defined as

$$
S_{i j}^{n}=S_{0} \delta_{i j}
$$

171 where $\delta_{i j}$ is the Kronecker delta and

$$
S_{0}=\frac{216 v \sigma T}{\pi^{2} \rho D_{a}^{5}\left(\rho_{a} / \rho\right)^{2} C_{c}},
$$


medRxiv preprint doi: https://doi.org/10.1101/2020.05.14.20094821; this version posted May 18, 2020. The copyright holder for this preprint (which was not certified by peer review) is the author/funder, who has granted medRxiv a license to display the preprint in perpetuity.

It is made available under a CC-BY-NC 4.0 International license.

173 where $T$ is the absolute temperature and $v$ is the kinematic viscosity.

174 Taken together, eqs. (1) to (8) show that airflow and transmission characteristics of aerosols

175 depend on the size, material density, surface charge and morphology of the aerosol as well as the 176 composition, flow and temperature of the surrounding gas.

177 While, at the time of writing, ${ }^{12}$ Covid-19 is believed to be communicated through the droplet 178 and contact modes of transmission, ${ }^{13,14}$ aerosol-generating medical procedures (AGMPs)

179 discharge aerosols (conventionally, $<5 \mu \mathrm{m}$ ), potentially leading to nosocomial infection. ${ }^{15}$ Other 180 infectious diseases, such as influenza, can induce respiratory infection via the airborne mode of 181 transmission. Both SARS-CoV-2 and influenza virions are approximately $0.1 \mu \mathrm{m}$ in size and can

182 be spherical. ${ }^{16,17}$ Infectious aerosols and droplet nuclei carrying SARS-CoV-2 and influenza are 183 largely spherical, have a material density of approximately $1 \mathrm{~g} \mathrm{~cm}^{-3}$, have a $\zeta$-potential modestly 184 below zero and are polydisperse but, by definition, $>0.1 \mu \mathrm{m}$ based on the size of the virions. ${ }^{18-20}$

185 For this study, we considered the above parameters and healthcare-relevant experimental 186 conditions to investigate how aerosols penetrate through and leak into N95 FFRs. We chose a 187 polydisperse $(0.1$ to $1.0 \mu \mathrm{m})$ challenge aerosol of spherical Latex polystyrene beads (material 188 density, $1.05 \mathrm{~g} \mathrm{~cm}^{-3} ; \zeta$-potential $<0$, although aerosols were charge neutralized during 189 experimentation for a $\zeta$-potential modestly below zero). Preliminary findings showed that

190 penetration followed a power relationship with aerosol size so that the behavior of aerosols larger

191 than $1.0 \mu \mathrm{m}$ could be extrapolated using the experimental size range; we did not include aerosols

192 between 1 and $5 \mu \mathrm{m}$ in this study. For our experimental conditions, we simulated ambient 193 healthcare conditions and its gaseous phase, accounting for the relevant density, dynamic 194 viscosity, breathing rates, ambient temperature, relative humidity $(\mathrm{RH})$, ambient pressure. 195 Further details are included in the Methods section below. 
medRxiv preprint doi: https://doi.org/10.1101/2020.05.14.20094821; this version posted May 18, 2020. The copyright holder for this preprint (which was not certified by peer review) is the author/funder, who has granted medRxiv a license to display the preprint in perpetuity.

It is made available under a CC-BY-NC 4.0 International license .

\section{Methods}

\section{Implementation of reprocessing methods for N95 FFRs}

The seven reprocessing methods assessed in this study include traditional sterilization and decontamination methods in medical settings, emerging ones and processes that have received emergency use authorization (EUA) from the U.S. Federal Drug Administration (FDA). ${ }^{21-27}$ Each reprocessing method, and number of cycles $(1,3,5$ or 10), was evaluated against three models of NIOSH-approved N95 FFRs (3M 1860S, 3M 8210 and 3M 9210, The 3M Company, St. Paul, MN, USA). These models are used widely by healthcare workers (HCWs) and vary in mask design (molded or pleated), strap material (polyisoprene, thermoplastic elastomer and blue polyisoprene for 3M 1860S, 3M 8210 and 3M 9210, respectively) and the presence (3M 1860S) or absence of a colored dye on the exterior surface. All reprocessed N95 FFRs were characterized for leakage or penetration after one day or longer after the last cycle was completed, as described below. Each reprocessing cycle was run using standard parameters or one that have been reported as used for decontamination. ${ }^{21-27}$

For autoclave reprocessing, the N95 FFRs were placed inside of a benchtop autoclave sterilizer (3850E Autoclave, Tuttnauer, Hauppauge, NY, USA), such that no FFR touched another one. For each cycle, they were run under the dry setting (steam time, 30 min) with a 60min dry time. The N95 FFRs were removed from the autoclave and allowed to sit idly in ambient conditions (30 $\mathrm{min})$ before proceeding.

For vEtOH (70\%) reprocessing, we prepared $70 \% \mathrm{EtOH}$ by mixing the appropriate ratio of ethanol (Sigma-Aldrich, Oakville, ON, Canada) with MilliQ water (18.2 M $\Omega \mathrm{cm}$, Milli-Q® IQ 7000 Ultrapure Lab Water System; Millipore Sigma, Etobicoke, ON, Canada). A vapor, vEtOH (70\%), was generated via a thin-layer chromatography atomizer (Chemglass Life Sciences, 
medRxiv preprint doi: https://doi.org/10.1101/2020.05.14.20094821; this version posted May 18, 2020. The copyright holder for this preprint (which was not certified by peer review) is the author/funder, who has granted medRxiv a license to display the preprint in perpetuity.

It is made available under a CC-BY-NC 4.0 International license.

219 Vineland, NJ, USA) and a fume hood air supply (operated at 25 psi). For each cycle, the N95

220 FFRs were covered with vEtOH (70\%) and allowed to dry completely under hood ventilation $(\sim 1$

221 h) before proceeding.

222 For forced-air dry heat $\left(100^{\circ} \mathrm{C}\right)$ reprocessing, the N95 FFRs were placed within a benchtop

223 forced air oven (chamber volume, $3.65 \mathrm{ft}^{3}$, VWR® Forced Air Oven; VWR International,

224 Mississauga, ON, Canada), such that no FFR touched another one. For each cycle, the N95 FFRs

225 were heated to $100{ }^{\circ} \mathrm{C}$ (ramp time, $\sim 2 \mathrm{~min}$ ) for $30 \mathrm{~min}$. Afterwards, they were removed from the

226 heat and allowed to cool down to and sit idly at room temperature in ambient conditions (30 min)

227 before proceeding.

228 For humid heat $\left(75 \% \mathrm{RH}, 75^{\circ} \mathrm{C}\right)$ reprocessing, the N95 FFRs were enclosed within

229 STERIL-PEEL ${ }^{\circledR}$ sterilization pouches (GS Medical Packaging, Inc., Etobicoke, ON, Canada)

230 and placed in a convection heating system with controlled humidity (HCSS74W12, Climate

231 Select Heated Holding Cabinet with Humidity, BevLes Company, Inc., Erie, PA, USA). A

232 humidity gauge (PT2470 Digital Combometer, Exo Terra, Montreal, QC, Canada) was used to

233 ensure that the RH was maintained. For each cycle, the N95 FFRs were heated at $75^{\circ} \mathrm{C}$ with

$23475 \% \mathrm{RH}$ for $1 \mathrm{~h}$. Afterwards, N95 FFRs were removed from the heat and allowed to cool down

235 in ambient conditions ( $5 \mathrm{~min}$ ) before proceeding.

236 For HPGP reprocessing, the N95 FFRs were enclosed within Tyvek ${ }^{\circledR}$ self-seal sterilization

237 pouches (GS Medical Packaging, Inc., Etobicoke, ON, Canada) and placed in a STERRAD®

238 100S Sterilizer (Advanced Sterilization Products, Irvine, CA, USA). The N95 FFRs were run

239 through the STERRAD® $100 \mathrm{~S}$ Long Cycle $\left(59 \% \mathrm{H}_{2} \mathrm{O}_{2}\right.$; approximately 72 min per cycle,

240 including venting; $42-50^{\circ} \mathrm{C}$; cycle pressure, fluctuated from vacuum to sterilant injection and

241 diffusion to plasma settings with range of 0.3-14.0 Torr). STERRAD® chemical indicator strips 
medRxiv preprint doi: https://doi.org/10.1101/2020.05.14.20094821; this version posted May 18, 2020. The copyright holder for this preprint (which was not certified by peer review) is the author/funder, who has granted medRxiv a license to display the preprint in perpetuity.

It is made available under a CC-BY-NC 4.0 International license.

242 (Advanced Sterilization Products, CA, USA) within the sterilization pouches verified exposure

243 during each cycle. The enclosed N95 FFRs were handled after venting.

244 For HPV reprocessing, the N95 FFRs were enclosed within Vis-U-A11 ${ }^{\mathrm{TM}}$ Low Temperature

245 Sterilization Pouches (STERIS Corporation, OH, USA) and placed in a STERIS V-PRO® $\operatorname{maX}$

246 Low Temperature Sterilization System (STERIS Corporation, OH, USA). Each cycle was run

247 under the non-lumen cycle settings $\left(59 \% \mathrm{H}_{2} \mathrm{O}_{2}\right.$, approximately 28 min per cycle, including

248 aeration, $49.3-50.6^{\circ} \mathrm{C}$; cycle pressure, fluctuated from vacuum to sterilant injection settings with

2494 pulsations varying from 1-504 Torr). Chemical indicator strips (STERIS Corporation, Ohio,

250 USA) within the sterilization pouches verified exposure during each cycle. The enclosed N95

251 FFRs were handled after aeration.

252 For UVGI reprocessing, we constructed an aluminum enclosure containing a SaniRay®

253 RRDHO36-4S High-Output Germicidal Ultraviolet Fixture (Atlantic Ultraviolet Corporation,

254 Hauppauge, NY, USA) with four 254-nm UVC lamps (UV 05-1060-R, Atlantic Ultraviolet

255 Corporation, Hauppauge, NY, USA) mounted in parallel. The enclosure measured $106.68 \mathrm{~cm} \mathrm{x}$

$256 \quad 60.96 \mathrm{~cm} \times 60.96 \mathrm{~cm}$ and was built with an aluminum door to safely introduce and remove

257 samples while containing radiation during operation. A height-adjustable platform was installed

258 and set to $30.48 \mathrm{~cm}$ below the lamps for this application. The lamps were warmed up (2 h) to

259 stabilize the UVC irradiance. A UV512C Digital UVC Light Meter (General Tools \&

260 Instruments, Secaucus, NJ, USA) was used inside of the enclosure at a fixed position to account

261 for potential fluctuations of UVC irradiation. The UVC irradiance at different areas on the N95

262 FFRs were mapped using a USB4000 fiber optic spectrometer (Ocean Optics, Dunedin, FL,

263 USA) with a CC-3 Cosine Corrector (Ocean Optics, Dunedin, FL, USA) using 25-scan averages.

264 The results indicated that for the face-side up orientation, the edges of the mask received $57.6 \%$ 
medRxiv preprint doi: https://doi.org/10.1101/2020.05.14.20094821; this version posted May 18, 2020. The copyright holder for this preprint (which was not certified by peer review) is the author/funder, who has granted medRxiv a license to display the preprint in perpetuity.

It is made available under a CC-BY-NC 4.0 International license .

265 of the irradiance, while the center of the mask received $145.3 \%$ of the dose, based on the

266 reference UVC meter. For the face-side down orientation, zones with the lowest irradiance and

267 highest irradiance received $79.4 \%$ and $137.3 \%$ of the measured reference irradiance,

268 respectively. The N95 FFRs were placed within the UVC enclosure and irradiated face-side up

269 such that all areas on the face-side up orientation received a minimum of $\sim 0.5 \mathrm{~J} / \mathrm{cm}^{2}$, while being

270 rotated $90^{\circ}$ in 30 -s intervals to ensure homogeneous dosing. The FFRs were then flipped face-

271 side down and irradiated in the same manner. The process was repeated such that all areas of the

272 N95 FFRs received $\sim 1 \mathrm{~J} / \mathrm{cm}^{2}$ of UVC or greater. The least exposed areas of the face-up

273 orientation received a UVC dose of $1.010 \pm 0.035 \mathrm{~J} / \mathrm{cm}^{2}$ at an irradiance of $2431 \pm 179 \mu \mathrm{W} / \mathrm{cm}^{2}$,

274 while the least exposed areas of the face-down orientation received $1.029 \pm 0.039 \mathrm{~J} / \mathrm{cm}^{2}$ at 3537

$275 \pm 199 \mu \mathrm{W} / \mathrm{cm}^{2}$.

276

277 Characterization of leakage

278 We characterized leakage via quantitative fit testing. For each pristine N95 FFRs, fit-verified

279 individuals donned and molded an N95 FFRs before assessing leakage. For each reprocessed

280 N95 FFRs, fit-verified individuals (fit factor for pristine masks, 200+) donned and molded an

281 N95 FFRs, doffed it, had it reprocessing using the specified method and number of cycles, and

282 re-donned and molded it to assess leakage. Fit testing was performed using the CSA Z94.4-11

283 testing standard (PortaCount Respirator Fit Tester 8048, TSI Incorporated, Shoreview, MN,

284 USA), fulfilling OSHA 29CFR 1910.134. Briefly, a sequence of breathing exercises (normal

285 breathing, deep breathing, breathing while turning head side to side, breathing while nodding

286 head up and down, breathing while talking out loud, breathing while bending over and, again,

287 normal breathing) was performed in the proximity of an aerosol generator (Model 8026, TSI 
medRxiv preprint doi: https://doi.org/10.1101/2020.05.14.20094821; this version posted May 18, 2020. The copyright holder for this preprint (which was not certified by peer review) is the author/funder, who has granted medRxiv a license to display the preprint in perpetuity.

It is made available under a CC-BY-NC 4.0 International license.

Incorporated; generated aerosols containing $\mathrm{NaCl}$ particles, $0.02 \mu \mathrm{m}$ to $>1.0 \mu \mathrm{m})$. Since the testing standard and the condensation nuclei counter within the PortaCount instrument exclusively assesses particles between 40 and $70 \mathrm{~nm}$, only particles that leaked through imperfections in facial seal were quantified, rather than those that penetrate through the filter media. These results correspond to leakage due to larger aerosols. ${ }^{28}$

Fit factor $(F F)$ is defined by

where $f f_{i}$ is the individual fit score for the $i$-th exercise. Since $F F$ is the mean geometric ratio between the concentrations of the test aerosol inside and outside of the N95 FFR $\left(C_{\text {in }} / C_{\text {out }}\right)$,

297 leakage was calculated as the inverse $\left(L=F F^{-1}\right)$. Within the relevant aerosol size range,

298 leakage is a bulk, size-independent measurement, as leakage occurs through macroscopic

299 imperfection of facial seal. Hence, we took leakage to be a constant value throughout the

300 penetration challenge aerosol range $(0.1$ to $1.0 \mu \mathrm{m})$ when calculating overall transmission. To

301 ensure consistent results (sensitivity, 0.10\%), ambient counts were generally maintained above

302150 throughout each test. The output value of the testing standard saturates at $200+$. Since an 303 output $F F$ of 200 corresponds to a leakage of $0.5 \%$ and the sensitivity was $0.10 \%$, we considered 304 the limit of detection to be $0.49 \%$.

305 For reprocessed N95 FFRs, leakage measurements were ensured to exclusively quantify the

306 effect of reprocessing. When re-donning a reprocessed N95 FFR, there is a risk that leakage

307 occurs due to human-based error. To mitigate this issue, fit-verified individuals re-donned

308 reprocessed N95 FFRs while viewing the live $F F$. The live $F F$ was maximized before testing,

309 meaning that increases in leakage were due to the effects of a reprocessing method and number 310 of cycles. 
medRxiv preprint doi: https://doi.org/10.1101/2020.05.14.20094821; this version posted May 18, 2020. The copyright holder for this preprint (which was not certified by peer review) is the author/funder, who has granted medRxiv a license to display the preprint in perpetuity.

It is made available under a CC-BY-NC 4.0 International license .

HCWs widely exhibit one or more behaviors of improper wear for N95 FFRs, such as

312 pinching the nose clip while molding the mask. ${ }^{29,30} \mathrm{We}$ simulated this common compliance

313 issue. Fit-verified individuals donned and molded a pristine N95 FFR without viewing the live

$314 F F$. While doing so, they molded the nose clip outward in, rather than the recommended inward

315 out, thereby pinching the nose clip and creating a relatively sharp bend at the apex of the nose

316 clip. Leakage was then quantified for these masks.

\section{Characterization of penetration and pressure differential}

Penetration experiments were performed at SGS-IBR Laboratories (Grass Lakes, MI, USA).

320 These aerosols and experimental conditions simulated those found in healthcare settings and for

321 moderate HCW breathing through N95 FFRs. ${ }^{31,32}$ To standardize experimentation, penetration

322 measurements were conducted according to particle filtration efficiency measurements for

323 ASTM F2299 and ASTM F2100..$^{33,34}$ As previously introduced, we characterized penetration

324 using a polydisperse aerosol of negatively charged spherical Latex polystyrene beads. Briefly,

325 we mixed monodisperse aqueous suspensions of Latex polystyrene microspheres for a

326 polydisperse distribution of challenge particles $\left(0.1 \mu \mathrm{m}\right.$ to $1 \mu \mathrm{m}$; material density, $1.05 \mathrm{~g} \mathrm{~cm}^{-3}$ at

$32720^{\circ} \mathrm{C}$ ). Filtered and dried air was passed through a nebulizer to produce an aerosol containing

328 the suspended Latex microspheres. The aerosol was passed through a charge neutralizer, leading

329 to a $\zeta$-potential modestly below 0 , and mixed and diluted with additional preconditioned air to

330 produce the challenge aerosol to be used in the test. N95 FFRs were tested previously for leakage

331 and contained fit test sampling probes (TSI Incorporated, Shoreview, MN, USA). Leftover

332 sample probes were sealed with hot glue, and control N95 FFRs with sealed probes were

333 indistinguishable from control ones without them based on penetration and pressure differential 
medRxiv preprint doi: https://doi.org/10.1101/2020.05.14.20094821; this version posted May 18, 2020. The copyright holder for this preprint (which was not certified by peer review) is the author/funder, who has granted medRxiv a license to display the preprint in perpetuity.

It is made available under a CC-BY-NC 4.0 International license .

measurements. N95 FFRs were attached to a filter holder and placed between inflow and outflow tubes. The aerosol was fed $(1.0 \mathrm{scfm})$ through the FFRs, and penetration was obtained using two particle counters (Lasair ${ }^{\circledR}$ III 110 Airborne Particle Counter, Particle Measuring Systems ${ }^{\circledR}$, a

337 Spectris company Boulder, CO, USA) connected to the feed stream and filtrate. Penetration was 338 measured within six size channels $(0.1$ to $0.15 \mu \mathrm{m}, 0.15$ to $0.20 \mu \mathrm{m}, 0.20$ to $0.25 \mu \mathrm{m}, 0.25$ to

$3390.30 \mu \mathrm{m}, 0.3$ to $0.5 \mu \mathrm{m}$ and 0.5 to $1.0 \mu \mathrm{m}$ ). For power regression (described in the section 340 below), we took the measured penetration within each channel to be the middle of its size 341 channel $(0.125 \mu \mathrm{m}, 0.175 \mu \mathrm{m}, 0.225 \mu \mathrm{m}, 0.275 \mu \mathrm{m}, 0.4 \mu \mathrm{m}$ and $0.75 \mu \mathrm{m})$. This was justified

342 based on high coefficients of determination $\left(R^{2}\right)$ throughout the samples in this study and

343 because expectation values for penetration were conservative estimates, with expected

344 penetration typically being slightly greater than the experimental values. Pressure differential

345 (DHII-007, Dwyer Instruments International, Michigan City, IN, USA), air flow (M-50SLPM-

346 D/5M, Alicat Scientific, Tucson, AZ, USA), temperature and humidity (HMT330 Humidity and

347 Temperature Meter, Vaisala, Helsinki, Finland) and barometric pressure (PTU200 Transmitter,

348 Vaisala, Helsinki, Finland) were also characterized in the experimental apparatus. Pressure

349 differential was measured for greater mechanistic insight into how reprocessing affected

350 penetration. ${ }^{26}$ Throughout the penetration experiments, the temperature, relative humidity and

351 barometric pressure were measured to be $20.9 \pm 0.52{ }^{\circ} \mathrm{C}, 48.5 \pm 3.70 \%$ and $723.6 \pm 2.72 \mathrm{mmHg}$,

352 respectively. Note that higher $\mathrm{RH}$ values (e.g., 80\%, like the preconditioning stage for the

353 NIOSH test) is not expected to affect penetration measurements. ${ }^{35}$

\section{Statistical analyses}

356 For power regression, the statistical model had the traditional nonlinear form, 
medRxiv preprint doi: https://doi.org/10.1101/2020.05.14.20094821; this version posted May 18, 2020. The copyright holder for this preprint (which was not certified by peer review) is the author/funder, who has granted medRxiv a license to display the preprint in perpetuity.

$$
\boldsymbol{y} \sim f(\boldsymbol{x}, \boldsymbol{\beta}) .
$$

358 We fitted the discrete aerosol penetration measurements for each sample according to the model

$$
P=c D_{a}^{-k}
$$

360 where $P$ is the expected penetration, $c$ is the scaling constant, $D_{a}$ is the aerosol size and $k$ is the

361 determined power law exponent. We used the least squares estimator

$$
\widehat{\boldsymbol{\beta}} \approx\left(\boldsymbol{J}^{T} \boldsymbol{J}\right)^{-1} \boldsymbol{J}^{T} \boldsymbol{y}
$$

and assumed that the model could be approximated using a first-order Taylor series

$$
f\left(x_{i}, \beta\right) \approx f\left(x_{i}, 0\right)+\sum_{j} \frac{\partial f\left(x_{i}, \beta\right)}{\partial \beta_{j}} \beta_{j} .
$$

365

Expectation curves and confidence bands were generated using these approximations at a sufficient number of intervals $(n=50)$ throughout the axes spans and by linearly connecting them. We applied power regression to the discrete penetration data from individual samples. A strong cumulative coefficient of determination $\left(R^{2}, 0.94 \pm 0.041\right.$, mean \pm S.E.M. $)$ across all samples in included in this study suggested that this power law was a good model for the relationship between penetration and aerosol size.

We performed equivalence testing to compare the likeness of the aerosol transmission characteristics of pristine N95 FFRs and reprocessed ones. We applied the conventional twoone-sided t-test procedure ${ }^{36}$ and took the ratio between overall transmission for all N95 FFRs, including across models, that were reprocessed using a certain method and number of cycles and all properly worn, pristine N95 FFRs. Since equivalence bounds are not standardized in this field, we used the U.S. FDA's standard bounds for bioequivalence (upper equivalence bound = 1.25 , lower equivalence bound $=0.80$, based on the geometric mean ratio). ${ }^{36}$ N95 FFRs reprocessed using each method for one cycle were tested first. For some reprocessing methods, our results showed rejection of the null hypothesis $(P<0.01$ and $P<0.001)$. If these reprocessed 
medRxiv preprint doi: https://doi.org/10.1101/2020.05.14.20094821; this version posted May 18, 2020. The copyright holder for this preprint (which was not certified by peer review) is the author/funder, who has granted medRxiv a license to display the preprint in perpetuity.

It is made available under a CC-BY-NC 4.0 International license .

380 masks accepted the null hypothesis $(P>0.05)$, we did not perform equivalence testing for higher

381 cycle numbers. N95 FFRs reprocessed using three methods passed at one cycle, but none did at

382 three cycles. 
medRxiv preprint doi: https://doi.org/10.1101/2020.05.14.20094821; this version posted May 18, 2020. The copyright holder for this preprint (which was not certified by peer review) is the author/funder, who has granted medRxiv a license to display the preprint in perpetuity.

It is made available under a CC-BY-NC 4.0 International license.

Limitations of this study

Composition of matter for N95 FFRs

The three models of N95 FFRs used in this study span a range of mask designs and constituent materials and are widely used by HCWs. Nevertheless, there are other models and

387 brands used by HCWs which may differ in the composition of matter. Of note, the three $3 \mathrm{M}$

388 models studied use an electret for the filter media that can restore static charge over time. ${ }^{37}$ Since

389 we found that reprocessing mainly increased aerosol penetration by degrading filter charge, our

390 results may underestimate the impact of certain reprocessing methods on aerosol penetration for

391 N95 brands and models without electret properties. The N95 FFRs used in this study included

392 those from several batches manufactured years apart. Differences arising from batch

393 manufacturing may be encapsulated in this study. Batch manufacturing may also skew the

394 transmission characteristics of an N95 FFR.

Relevance to reprocessing N95 FFRs in healthcare settings

This study focuses on the direct assessment of aerosol transmission for pristine, improperly

398 worn pristine and reprocessed, but properly worn, N95 FFRs. Our results help to understand the

399 exposure risk for HCWs performing AGMPs or near other sources of infectious aerosols. They

400 also help to understand the implications of reprocessing. We did not, however, investigate the

401 effects of HCW wear, especially when extended-use guidelines are implemented. In addition, the

402 field does not currently understand the extensiveness and impact of extended-use guidelines on

403 noncompliance in wear. These, and additional contributions, may adversely affect the aerosol

404 transmission characteristics of N95 FFRs in healthcare settings. For example, we showed that at

405 one cycle of forced-air dry heat, HPGP or HPV reprocessed N95 FFRs were statistically 
406 equivalent to pristine ones in terms of aerosol transmission. This result does not account for the

407 effects of extended wear, which may affect performance. In addition, for proper experimental

408 design, we evaluated leakage on fit-verified individuals who had an optimal fit factor (200+).

409 Since quantitative fit testing considers a fit factor of 100 to be a pass, some institutions may

410 allow HCWs to wear N95 FFRs that do not fit optimally, increasing leakage by a predictable

411 amount. From one perspective, the results in this study can be taken as approximate better-case

412 scenarios (i.e., upper bounds), especially for greater reprocessing cycle numbers. For proper

413 clinical implementation of reprocessing for N95 FFRs, the effects of the aforementioned

414 contributions on filtration performance should be studied. 


\section{Supplementary figures}
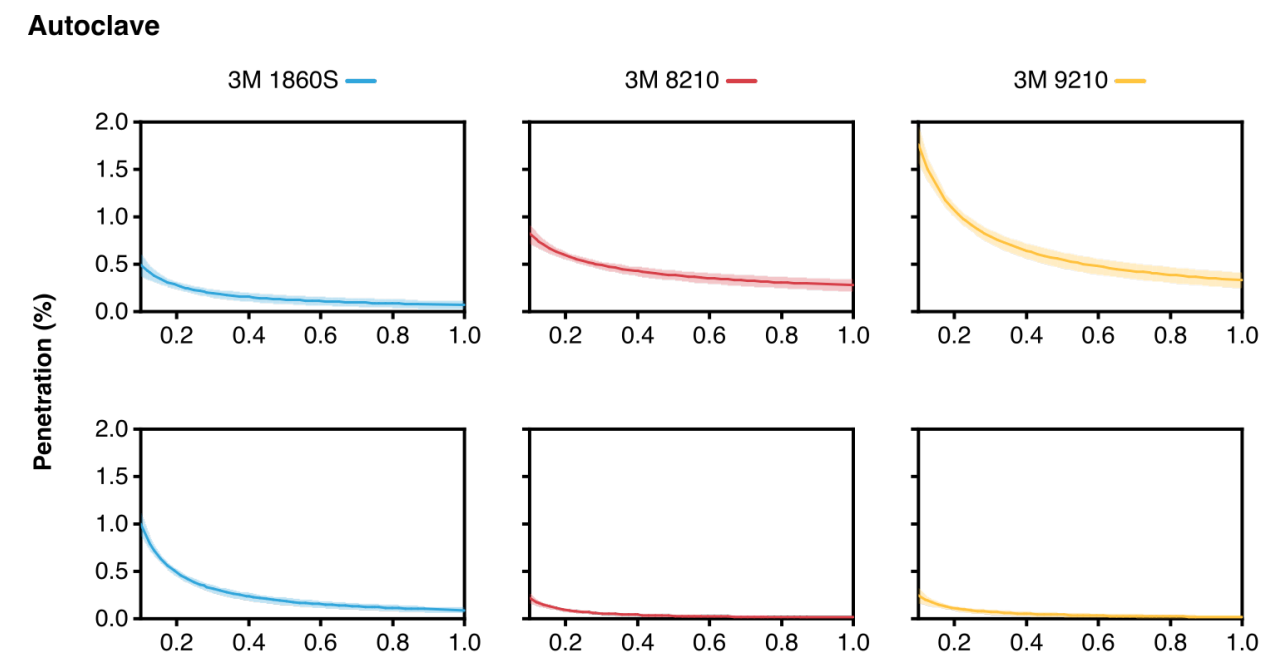

1 cycle
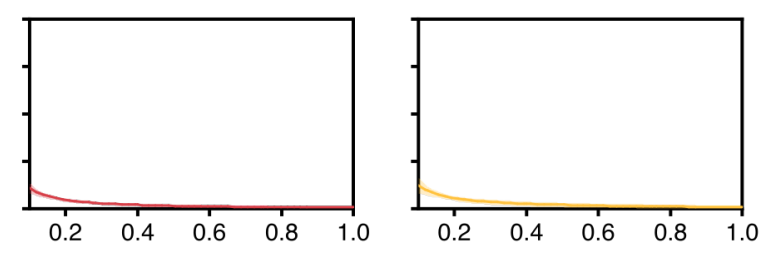

3 cycles

Challenge aerosol size $(\mu \mathrm{m})$

417 Figure S1. Penetration plots for N95 FFRs that were reprocessed via autoclave for 1 or 3 cycles.

418 Samples were not reprocessed using autoclave for 5 or 10 cycles. Curves and bands depict the

419 expectation line and its 95\% confidence band, respectively, from power regression for individual

420 samples. 
vEtOH

$3 \mathrm{M} 1860 \mathrm{~S}-$

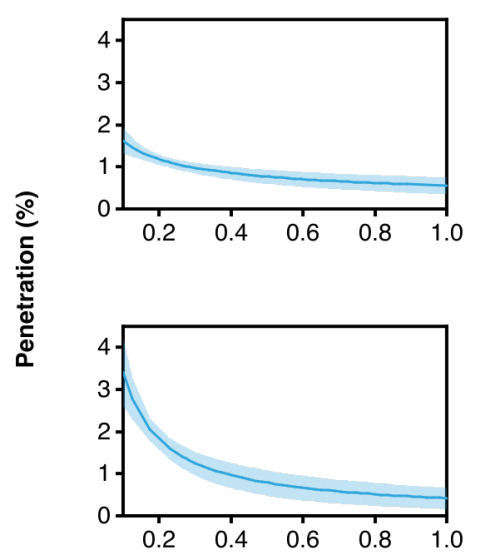

$3 \mathrm{M} 8210$
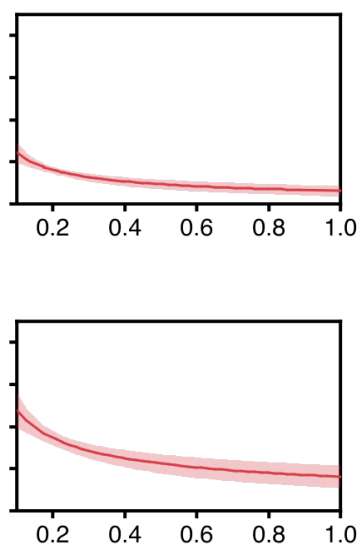

Challenge aerosol size ( $\mu \mathrm{m})$
$3 \mathrm{M} 9210$

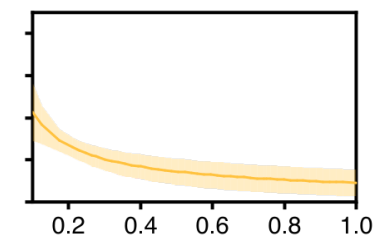

1 cycle

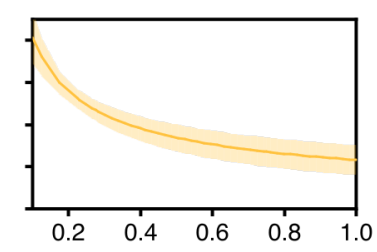

3 cycles

422 Figure S2. Penetration plots for N95 FFRs that were reprocessed via vEtOH (70\%) for 1 or 3

423 cycles. Samples were not reprocessed using autoclave for 5 or 10 cycles. Curves and bands

424 depict the expectation line and its 95\% confidence band, respectively, from power regression for

425 individual samples. 
medRxiv preprint doi: https://doi.org/10.1101/2020.05.14.20094821; this version posted May 18, 2020. The copyright holder for this preprint (which was not certified by peer review) is the author/funder, who has granted medRxiv a license to display the preprint in perpetuity.

It is made available under a CC-BY-NC 4.0 International license .

Forced-air dry heat
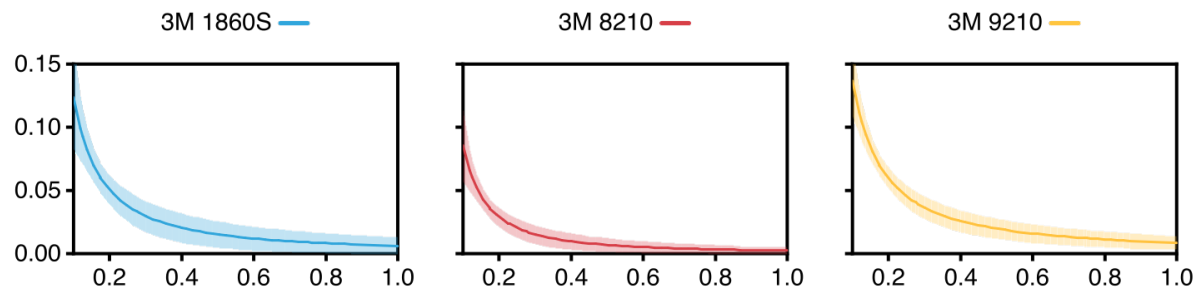

1 cycle
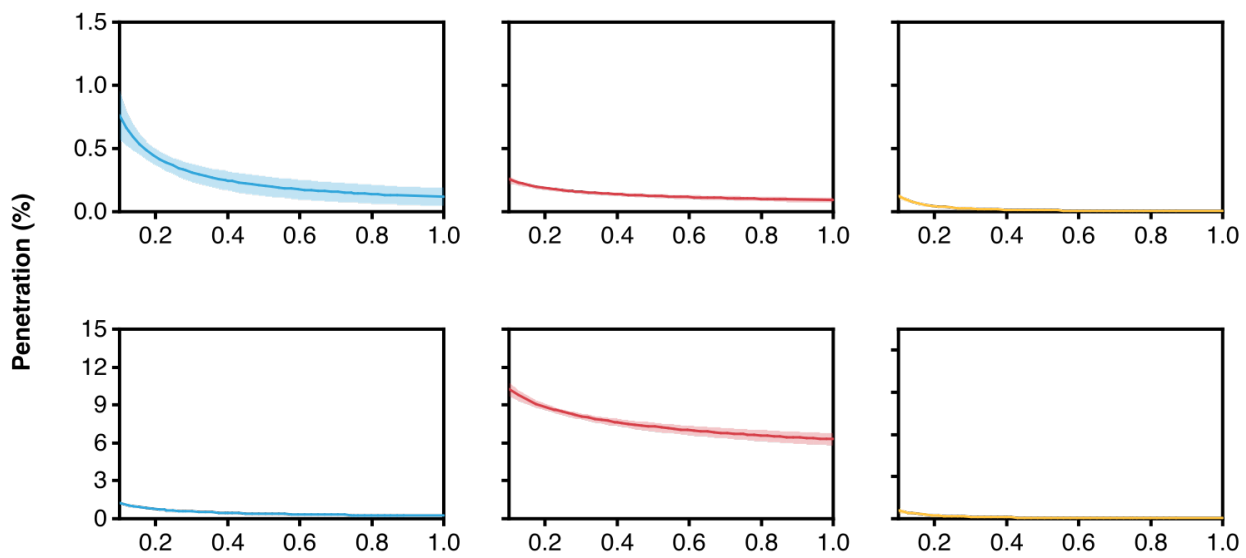

3 cycles
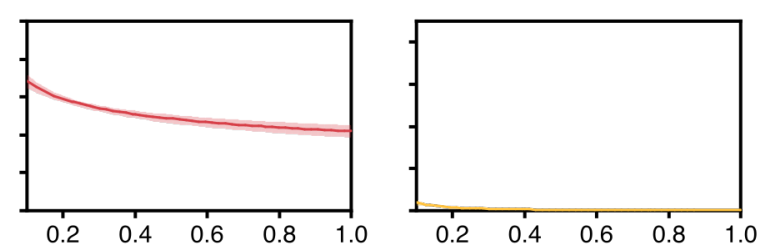

5 cycles
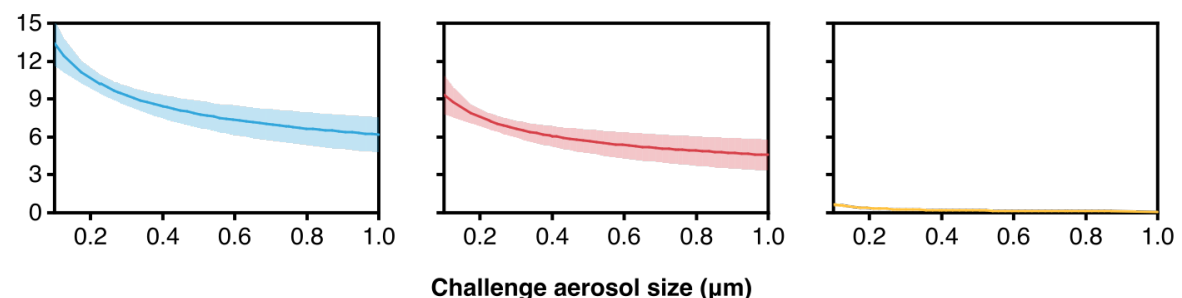

10 cycles

Challenge aerosol size $(\mu \mathrm{m})$

427 Figure S3. Penetration plots for N95 FFRs that were reprocessed via forced-air dry heat $\left(100^{\circ} \mathrm{C}\right)$

428 for 1, 3, 5 or 10 cycles. Curves and bands depict the expectation line and its $95 \%$ confidence

429 band, respectively, from power regression for individual samples. 
medRxiv preprint doi: https://doi.org/10.1101/2020.05.14.20094821; this version posted May 18, 2020. The copyright holder for this preprint (which was not certified by peer review) is the author/funder, who has granted medRxiv a license to display the preprint in perpetuity.

It is made available under a CC-BY-NC 4.0 International license .

Humid heat

$3 \mathrm{M} 1860 \mathrm{~S}$
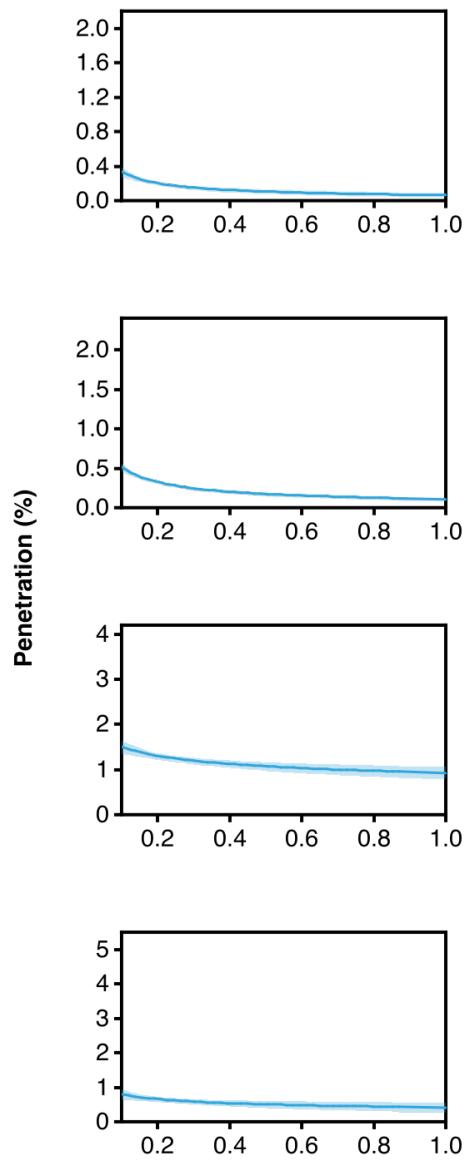

$3 \mathrm{M} 8210-$
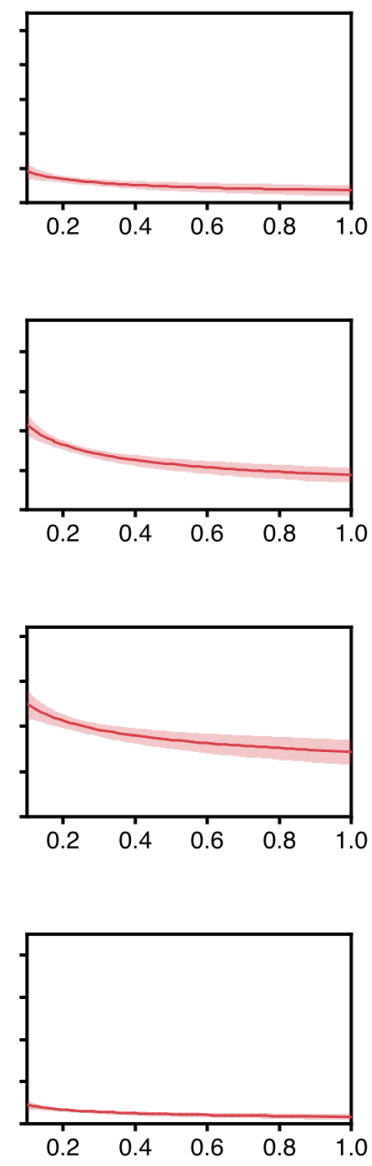

Challenge aerosol size $(\mu \mathrm{m})$
$3 \mathrm{M} 9210-$

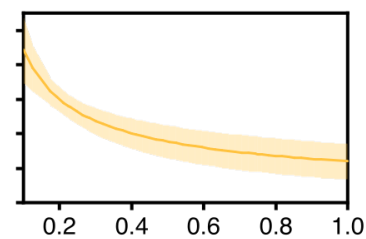

1 cycle

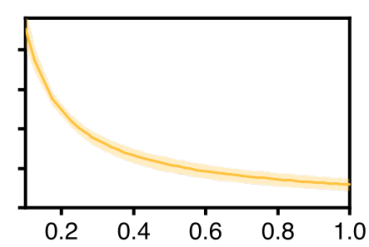

3 cycles

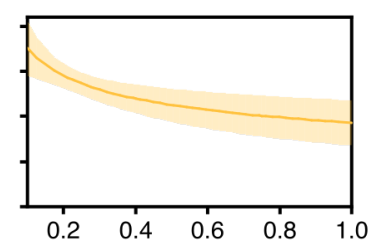

5 cycles

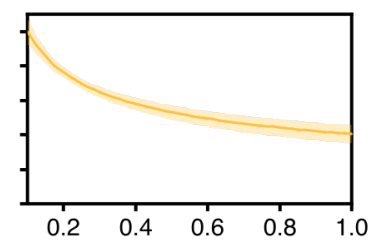

10 cycles

Figure S4. Penetration plots for N95 FFRs that were reprocessed via humid heat (75\% RH, 75

$432{ }^{\circ} \mathrm{C}$ ) for $1,3,5$ or 10 cycles. Curves and bands depict the expectation line and its $95 \%$ confidence

433 band, respectively, from power regression for individual samples. 
medRxiv preprint doi: https://doi.org/10.1101/2020.05.14.20094821; this version posted May 18, 2020. The copyright holder for this preprint (which was not certified by peer review) is the author/funder, who has granted medRxiv a license to display the preprint in perpetuity.

It is made available under a CC-BY-NC 4.0 International license .

HPGP
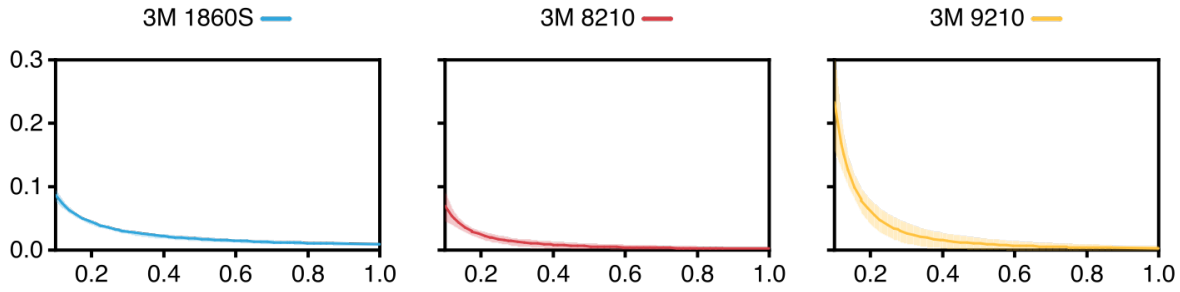

1 cycle
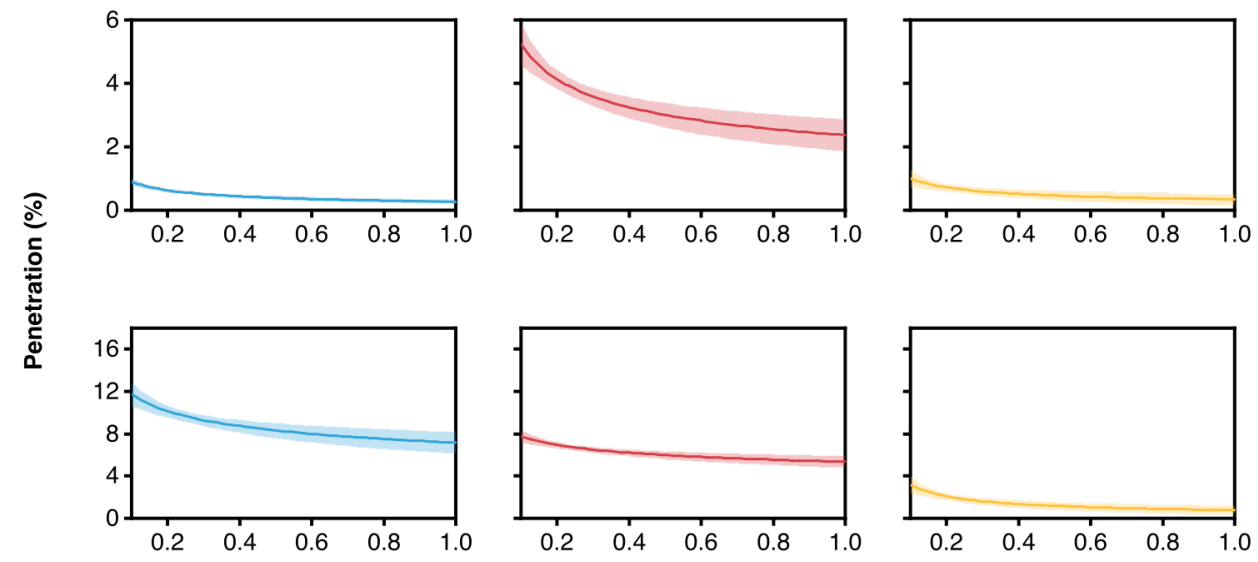

3 cycles
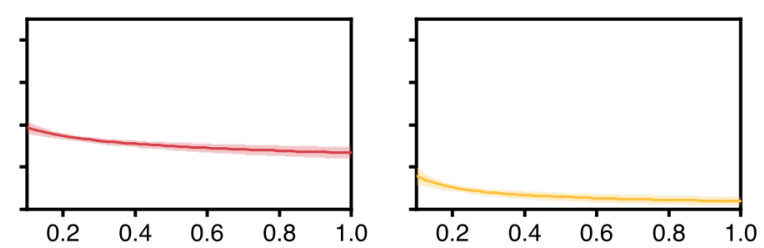

5 cycles
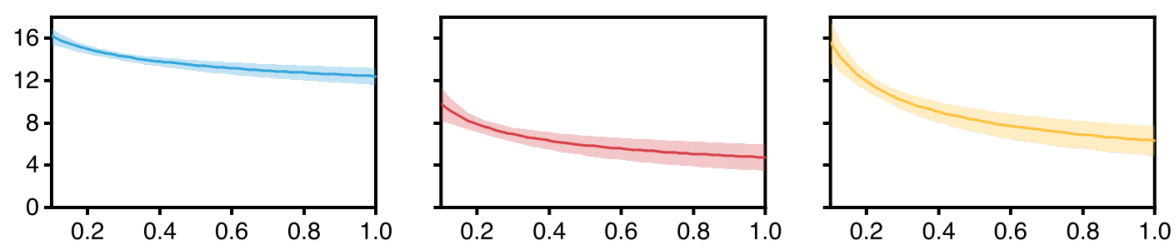

10 cycles

Challenge aerosol size $(\mu \mathrm{m})$

435 Figure S5. Penetration plots for N95 FFRs that were reprocessed via HPGP (STERRAD® ${ }^{100 S)}$

436 for $1,3,5$ or 10 cycles. Curves and bands depict the expectation line and its $95 \%$ confidence

437 band, respectively, from power regression for individual samples. 
HPV

$3 \mathrm{M} 1860 \mathrm{~S}-$
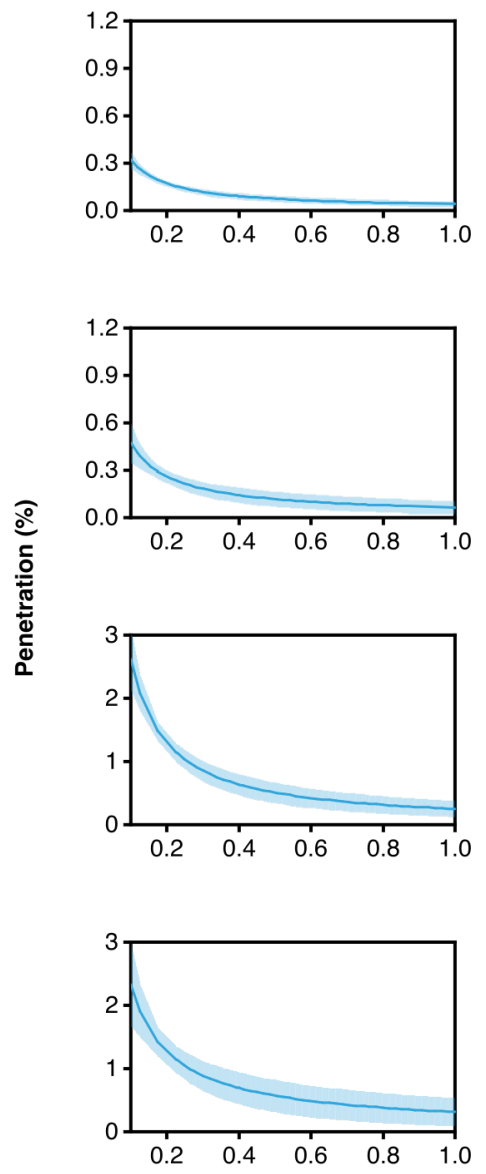

$3 \mathrm{M} 8210-$
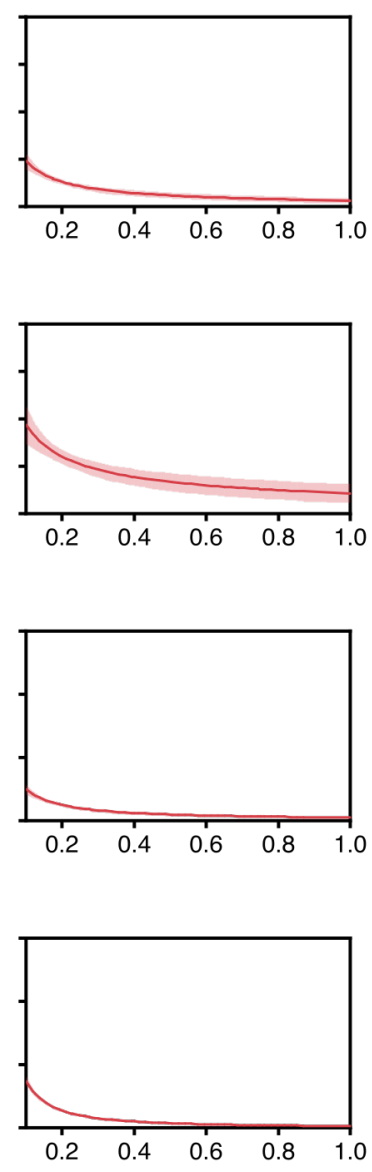

Challenge aerosol size $(\mu \mathrm{m})$

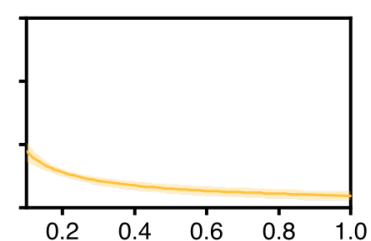

$3 \mathrm{M} 9210-$

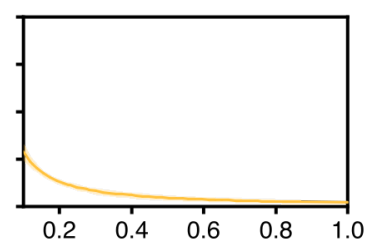

1 cycle

3 cycles

5 cycles

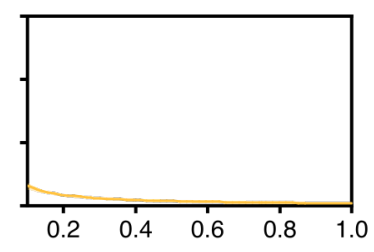

10 cycles

Figure S6. Penetration plots for N95 FFRs that were reprocessed via HPV (STERIS V-PRO®)

440 for $1,3,5$ or 10 cycles. Curves and bands depict the expectation line and its $95 \%$ confidence

441 band, respectively, from power regression for individual samples. 
UVGI
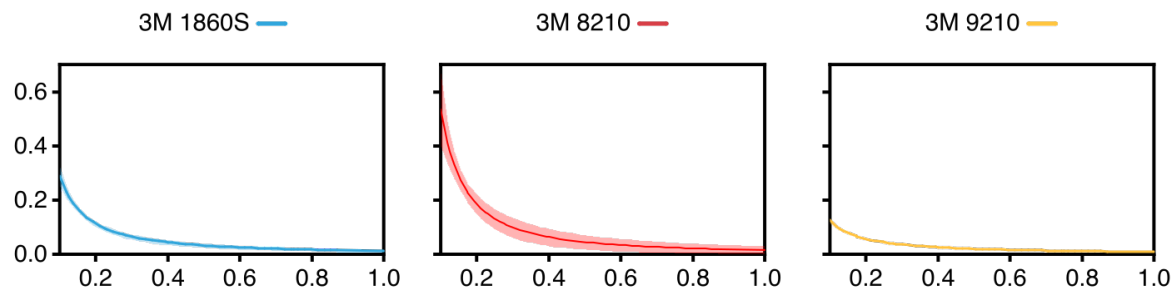

1 cycle
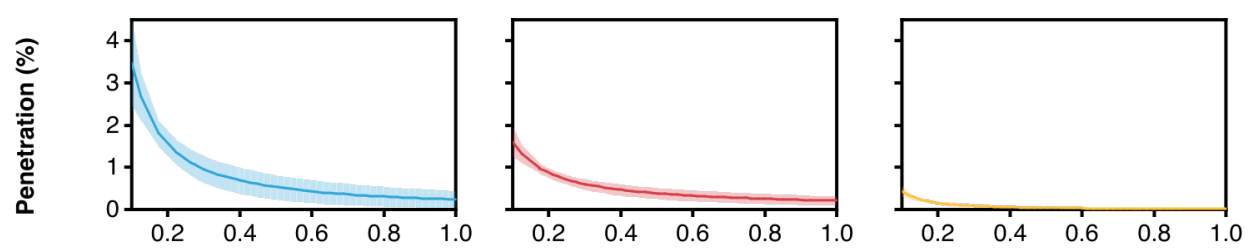

3 cycles
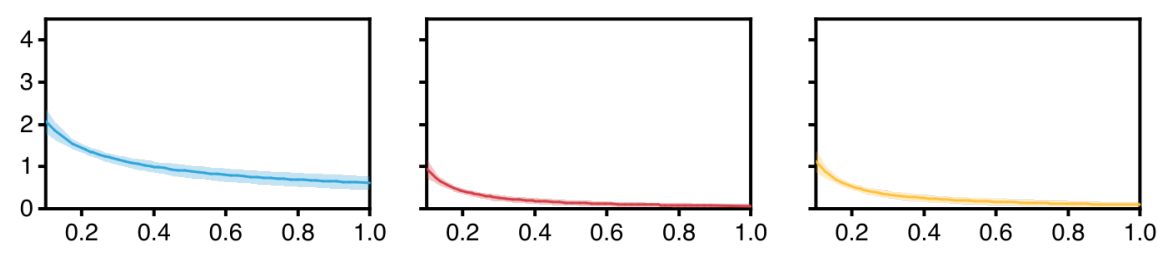

5 cycles

Challenge aerosol size $(\mu \mathrm{m})$

443 Figure S7. Penetration plots for N95 FFRs that were reprocessed via UVGI for 1, 3 or 5 cycles.

444 Samples were not reprocessed using autoclave for 10 cycles. Curves and bands depict the

445 expectation line and its $95 \%$ confidence band, respectively, from power regression for individual

446 samples. 
medRxiv preprint doi: https://doi.org/10.1101/2020.05.14.20094821; this version posted May 18, 2020. The copyright holder for this preprint (which was not certified by peer review) is the author/funder, who has granted medRxiv a license to display the preprint in perpetuity.

It is made available under a CC-BY-NC 4.0 International license .

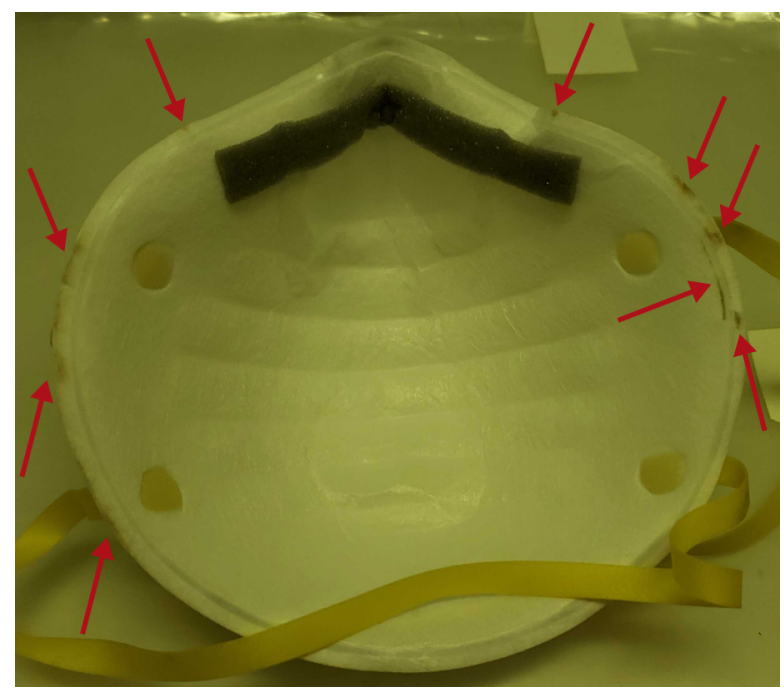

449 Figure S8. UVGI reprocessing can potentially induce dose-dependent photochemical damage to

450 N95 FFRs. Image of an N95 FFR (3M 8210) that has undergone 3 reprocessing cycles and

451 displays slight damage, as depicted by the red arrows. 
medRxiv preprint doi: https://doi.org/10.1101/2020.05.14.20094821; this version posted May 18, 2020. The copyright holder for this preprint (which was not certified by peer review) is the author/funder, who has granted medRxiv a license to display the preprint in perpetuity.

It is made available under a CC-BY-NC 4.0 International license .
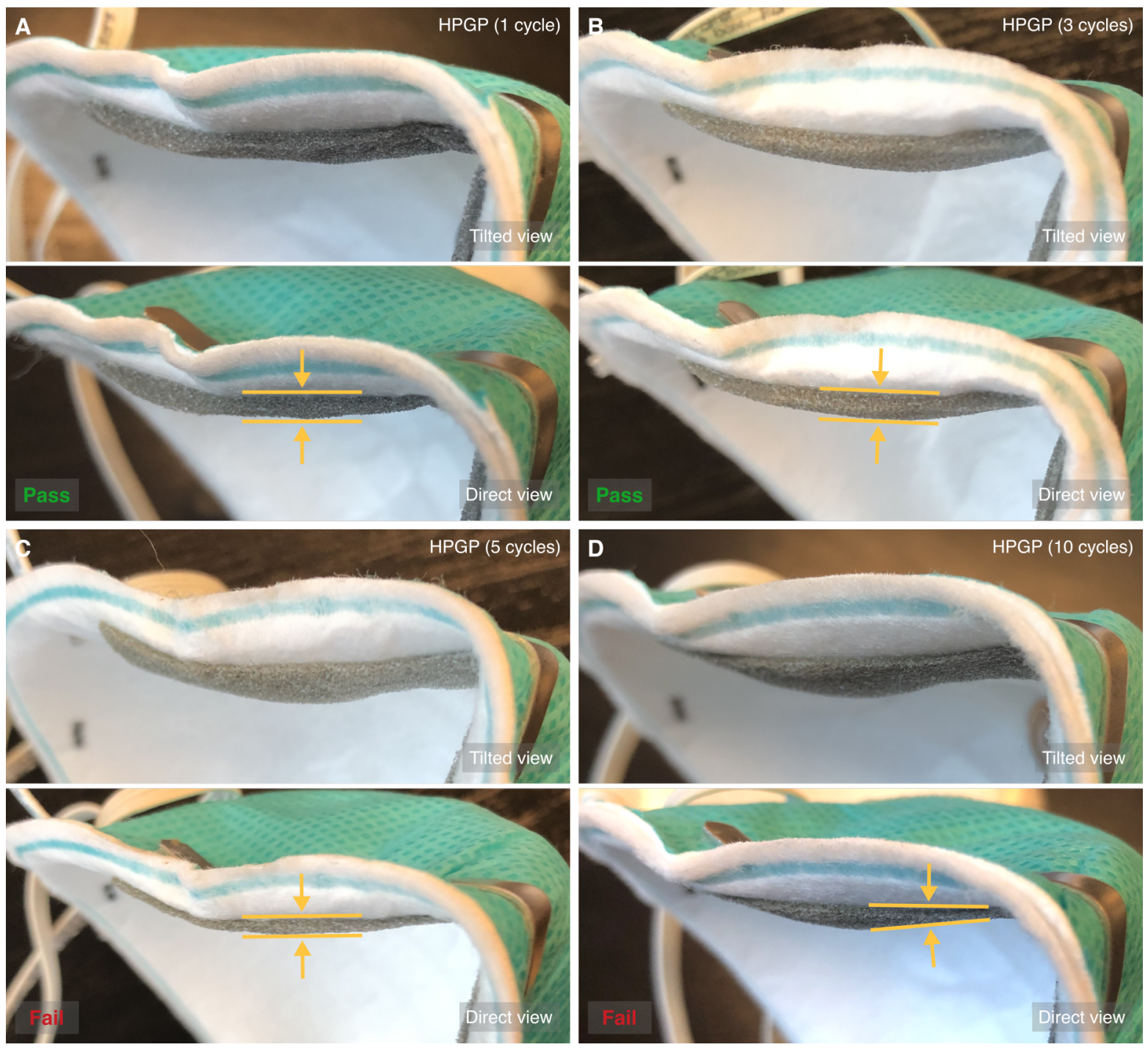

453 Figure S9. HPGP (STERRAD® 100S) reprocessing degrades the polyurethane nose foam of

454 N95 FFRs. Tilted (top) and direct (bottom) images of the nose foam of 3M 1860S FFRs after 1

455 cycle (A), 3 cycles (B), 5 cycles (C) and 10 cycles (D) of HPGP reprocessing. Pass or fail refers

456 to the results from quantitative fit testing. At 5 and 10 cycles, nose foams felt brittle. The yellow

457 markings denote the thickness of each nose foam. The HPGP and HPV cycles run are essentially

458 similar (e.g., $\mathrm{H}_{2} \mathrm{O}_{2}$ concentration and experimental conditions) except for the plasma phase of

459 HPGP. Since HPV did not induce nose foam degradation, these results suggest the hydroxyl and

460 hydroperoxyl radicals from the plasma oxidize the polyurethane nose foams across N95 models. 
medRxiv preprint doi: https://doi.org/10.1101/2020.05.14.20094821; this version posted May 18, 2020. The copyright holder for this preprint (which was not certified by peer review) is the author/funder, who has granted medRxiv a license to display the preprint in perpetuity.

It is made available under a CC-BY-NC 4.0 International license.
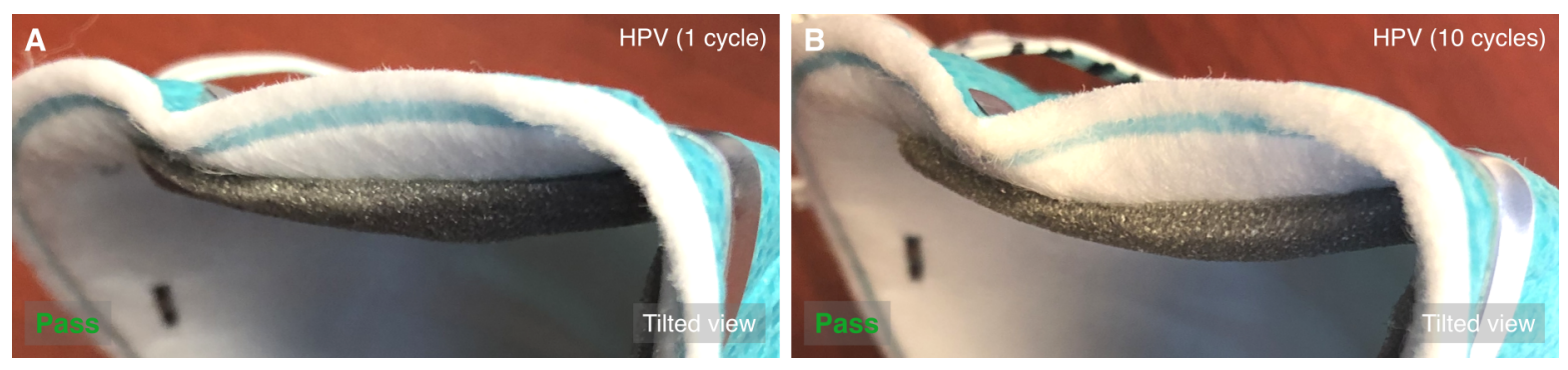

462 Figure S10. HPV (STERIS V-PRO® $\mathrm{maX}$ ) reprocessing maintains the polyurethane nose foam

463 of N95 FFRs for at least 10 cycles. Tilted images of the nose foam of 3M 1860S FFRs after 1

464 cycle (A) and 10 cycles (B) of HPV reprocessing. Pass refers to the results from quantitative fit

465 testing. In addition, there was no noticeable impact on the feel of the nose foam up to 10 cycles. 
A
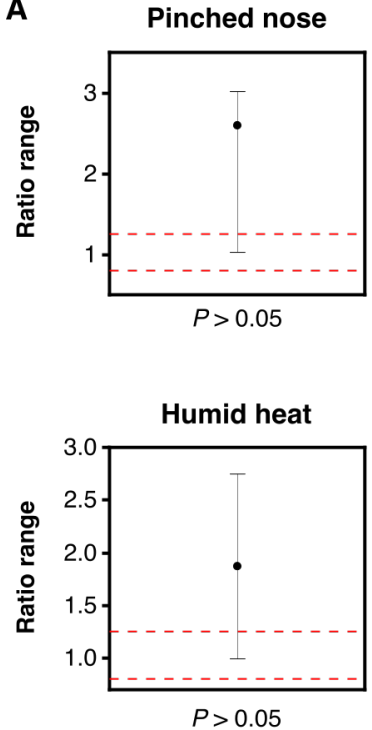

$P>0.05$
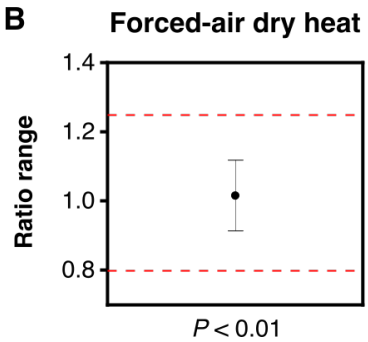

Autoclave

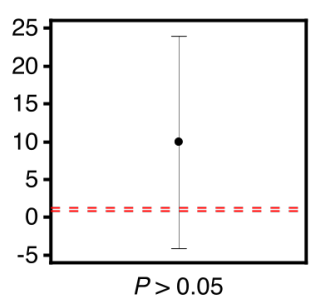

HPGP

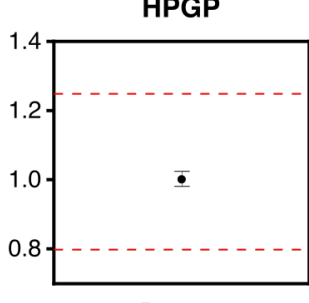

$P<0.05$

HPGP

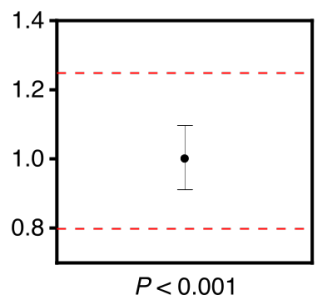

vEtOH

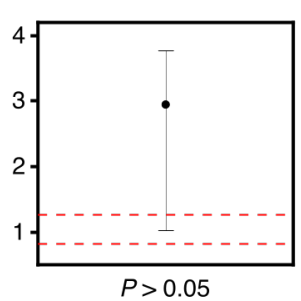

HPV
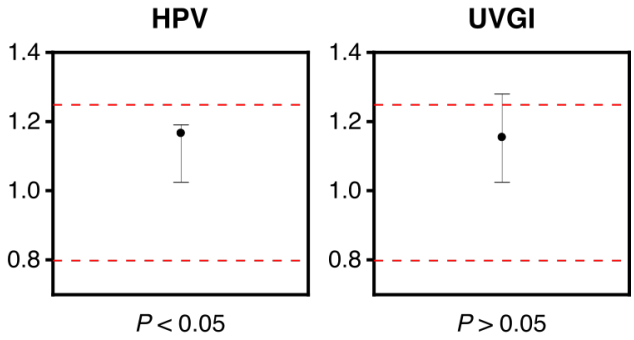

HPV

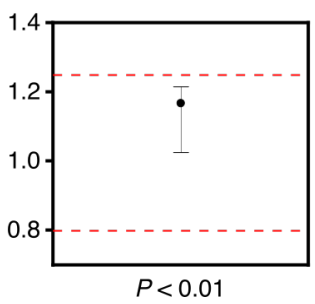

467 Figure S11. Equivalence testing compares the overall transmission of pristine N95 FFRs with

468 that of improperly worn N95 FFRs (pinched nose clip) or those that have been reprocessed for 1

469 cycle via the seven methods (geometric mean ratio, upper equivalence bound $=1.25$, lower

470 equivalence bound $=0.80$ ) with $\alpha=0.05$ (A) or $\alpha=0.01$ or $\alpha=0.001$ (B). The dots and I bars

471 represent the geometric mean ratios and their $100(1-2 \alpha) \%$ confidence intervals, respectively.

472 The red dashed lines represent the upper and lower equivalence bounds. The $P$-value inequalities

473 are reported below each plot. 

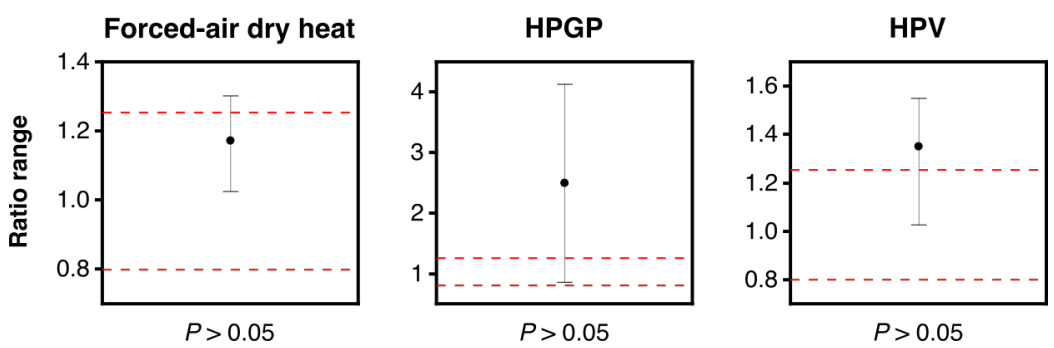

475 Figure S12. Equivalence testing compares the overall transmission of pristine N95 FFRs with 476 reprocessed ones for 3 cycles via forced-air dry heat $\left(100^{\circ} \mathrm{C}\right)$, HPGP (STERRAD® $\left.100 \mathrm{~S}\right)$ or

477 HPV (STERIS V-PRO ${ }^{\circledR}$ maX) (geometric mean ratio, upper equivalence bound $=1.25$, lower

478 equivalence bound $=0.80, \alpha=0.05)$. The dots and $\mathrm{I}$ bars represent the geometric mean ratios and

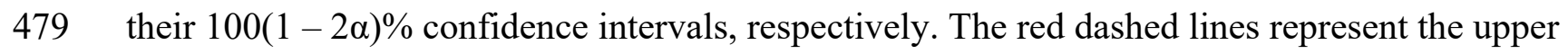

480 and lower equivalence bounds. The $P$-value inequalities are reported below each plot. 


\section{A Overall transmission (1 cycle for reprocessed N95 FFRs, at $0.3 \mu \mathrm{m}$ )}

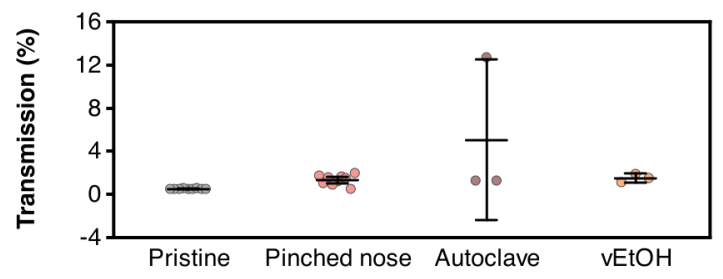

B Overall transmission (up to 3 cycles for reprocessed N95 FFRs, at $0.3 \mu \mathrm{m}$ )

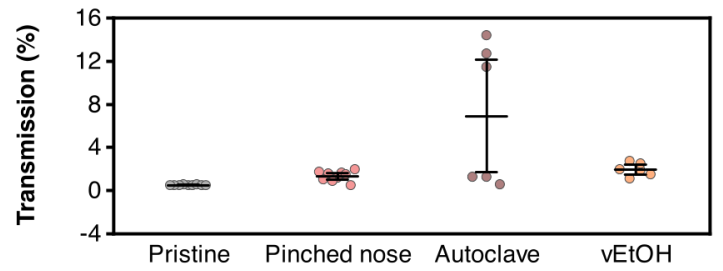

C Overall transmission (up to 5 cycles for reprocessed N95 FFRs, at $0.3 \mu \mathrm{m}$ )

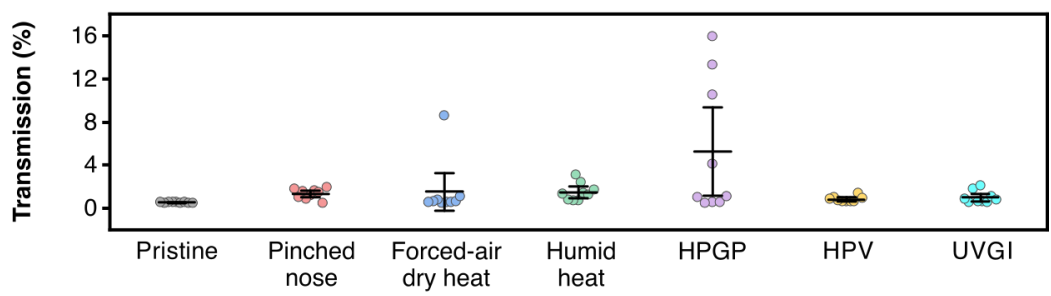

D Overall transmission (up to 10 cycles for reprocessed N95 FFRs, at $0.3 \mu \mathrm{m}$ )

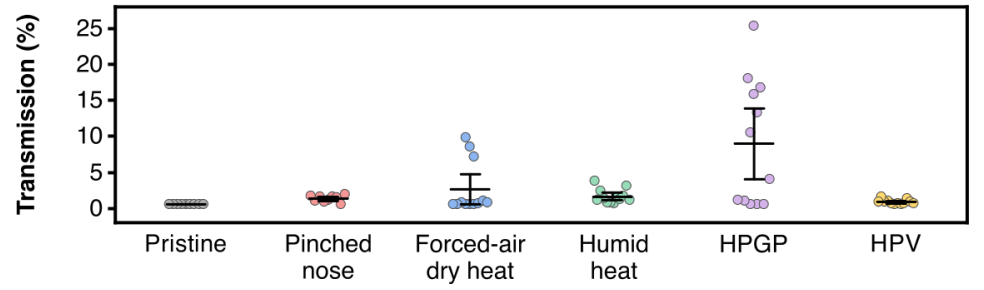

482 Figure S13. Comparison of the overall transmission for pristine N95 FFRs, improperly worn

483 pristine N95 FFRs (pinched nose clip) and those that have been reprocessed for 1 (A), 3 (B), 5

484 (C) or 10 (D) cycles. Individual data points represent the expectation values from power

485 regressions at an aerosol size of $0.3 \mu \mathrm{m}$. Data included in the main body (Fig. 1) are excluded in

486 this supplementary figure. A reprocessing method was excluded in (C) (autoclave and vEtOH)

487 and (D) (UVGI) if it was not run for the respective number of cycles. The middle bars and I bars

488 represent the estimate mean and its $95 \%$ confidence interval, respectively. 
medRxiv preprint doi: https://doi.org/10.1101/2020.05.14.20094821; this version posted May 18, 2020. The copyright holder for this preprint (which was not certified by peer review) is the author/funder, who has granted medRxiv a license to display the preprint in perpetuity.

It is made available under a CC-BY-NC 4.0 International license .

490

491 492

\section{Supplementary table}

Table S1. Summary of the aerosol transmission characteristics of pristine and reprocessed N95 FFRs.

\begin{tabular}{|c|c|c|c|c|c|c|c|}
\hline $\begin{array}{l}\text { Reprocessing } \\
\text { method }\end{array}$ & $\begin{array}{l}\text { Model of } \\
\text { N95 FFR } \\
\text { evaluated }\end{array}$ & $\begin{array}{c}\text { Number of } \\
\text { reprocessing } \\
\text { cycles }\end{array}$ & $\begin{array}{c}\text { Leakage } \\
(\%)^{\dagger}\end{array}$ & $\begin{array}{c}\text { Expected } \\
\text { penetration* } \\
(\%, 0.3 \mu \mathrm{m})\end{array}$ & $\begin{array}{l}\text { 95\% confidence } \\
\text { interval* }(\%)\end{array}$ & $\boldsymbol{R}^{2 *}$ & $\begin{array}{c}\text { Pressure } \\
\text { differential } \\
\left(\mathrm{mmH}_{2} \mathrm{O}\right) \\
\end{array}$ \\
\hline \multirow{3}{*}{$\begin{array}{l}\text { Pristine (not } \\
\text { reprocessed) }\end{array}$} & $3 \mathrm{M} \mathrm{1860S}$ & 0 & $\leq 0.49 \pm 0$ & 0.024 & $(0.013,0.035)$ & 0.94 & 3.6 \\
\hline & $3 \mathrm{M} 8210$ & 0 & $\leq 0.49 \pm 0$ & 0.025 & $(0.012,0.037)$ & 0.97 & 2.1 \\
\hline & $3 \mathrm{M} 9210$ & 0 & $\leq 0.49 \pm 0$ & 0.019 & $(0.013,0.024)$ & 0.97 & 2.8 \\
\hline \multirow{6}{*}{ Autoclave } & $3 \mathrm{M} \mathrm{1860S}$ & 1 & 12.50 & 0.195 & $(0.151,0.238)$ & 0.94 & 4.6 \\
\hline & & 3 & 11.11 & 0.315 & $(0.273,0.356)$ & 0.99 & 4.3 \\
\hline & $3 \mathrm{M} 8210$ & 1 & 0.74 & 0.488 & $(0.446,0.529)$ & 0.96 & 3.3 \\
\hline & & 3 & 14.29 & 0.057 & $(0.040,0.074)$ & 0.96 & 3.3 \\
\hline & $3 \mathrm{M} 9210$ & 1 & $\leq 0.49$ & 0.789 & $(0.717,0.860)$ & 0.99 & 3.3 \\
\hline & & 3 & $\leq 0.49$ & 0.071 & $(0.043,0.098)$ & 0.93 & 3.3 \\
\hline \multirow{6}{*}{ vEtOH $(70 \%)$} & $3 \mathrm{M} \mathrm{1860S}$ & 1 & 0.93 & 0.972 & $(0.845,1.099)$ & 0.92 & 3.6 \\
\hline & & 3 & 1.22 & 1.246 & $(0.963,1.528)$ & 0.95 & 4.3 \\
\hline & $3 \mathrm{M} 8210$ & 1 & $\leq 0.49$ & 0.633 & $(0.540,0.726)$ & 0.93 & 3.3 \\
\hline & & 3 & 0.52 & 1.424 & $(1.251,1.598)$ & 0.92 & 3.3 \\
\hline & $3 \mathrm{M} 9210$ & 1 & $\leq 0.49$ & 1.014 & $(0.750,1.278)$ & 0.87 & 3.8 \\
\hline & & 3 & $\leq 0.49$ & 2.228 & $(1.974,2.481)$ & 0.95 & 3.3 \\
\hline \multirow{12}{*}{$\begin{array}{c}\text { Forced-air } \\
\text { dry heat } \\
\left(100^{\circ} \mathrm{C}\right)\end{array}$} & $3 \mathrm{M} \mathrm{1860S}$ & 1 & 0.51 & 0.029 & $(0.017,0.042)$ & 0.94 & 4.6 \\
\hline & & 3 & $\leq 0.49$ & 0.310 & $(0.239,0.381)$ & 0.93 & 4.6 \\
\hline & & 5 & $\leq 0.49$ & 0.562 & $(0.531,0.594)$ & 0.99 & 4.6 \\
\hline & & 10 & 0.57 & 9.259 & $(8.478,10.040)$ & 0.93 & 4.3 \\
\hline & $3 \mathrm{M} 8210$ & 1 & $\leq 0.49$ & 0.010 & $(0.003,0.016)$ & 0.95 & 4.1 \\
\hline & & 3 & $\leq 0.49$ & 0.156 & $(0.145,0.167)$ & 0.97 & 3.6 \\
\hline & & 5 & $\leq 0.49$ & 8.107 & $(7.862,8.352)$ & 0.97 & 3.6 \\
\hline & & 10 & $\leq 0.49$ & 6.638 & $(5.955,7.322)$ & 0.87 & 3.3 \\
\hline & $3 \mathrm{M} 9210$ & 1 & $\leq 0.49$ & 0.036 & $(0.027,0.045)$ & 0.97 & 3.3 \\
\hline & & 3 & 0.55 & 0.024 & $(0.018,0.030)$ & 0.99 & 3.6 \\
\hline & & 5 & $\leq 0.49$ & 0.046 & $(0.028,0.065)$ & 0.95 & 3.3 \\
\hline & & 10 & 0.50 & 0.265 & $(0.199,0.331)$ & 0.93 & 3.8 \\
\hline \multirow{12}{*}{$\begin{array}{c}\text { Humid heat } \\
(75 \% \mathrm{RH}, \\
\left.75^{\circ} \mathrm{C}\right)\end{array}$} & $3 \mathrm{M} \mathrm{1860S}$ & 1 & 0.55 & 0.151 & $(0.129,0.173)$ & 0.96 & 4.1 \\
\hline & & 3 & 0.52 & 0.244 & $(0.225,0.263)$ & 0.99 & 4.1 \\
\hline & & 5 & 0.51 & 1.195 & $(1.127,1.263)$ & 0.91 & 4.3 \\
\hline & & 10 & 0.60 & 0.584 & $(0.510,0.658)$ & 0.80 & 4.3 \\
\hline & $3 \mathrm{M} 8210$ & 1 & 0.51 & 0.231 & $(0.192,0.270)$ & 0.84 & 3.0 \\
\hline & & 3 & 0.52 & 0.700 & $(0.643,0.758)$ & 0.95 & 3.0 \\
\hline & & 5 & $\leq 0.49$ & 1.924 & $(1.783,2.065)$ & 0.89 & 3.6 \\
\hline & & 10 & 0.83 & 0.280 & $(0.240,0.320)$ & 0.89 & 3.3 \\
\hline & $3 \mathrm{M} 9210$ & 1 & $\leq 0.49$ & 0.945 & $(0.793,1.098)$ & 0.93 & 3.6 \\
\hline & & 3 & $\leq 0.49$ & 0.849 & $(0.764,0.934)$ & 0.99 & 4.3 \\
\hline & & 5 & $\leq 0.49$ & 2.591 & $(2.325,2.858)$ & 0.83 & 3.3 \\
\hline & & 10 & 0.51 & 3.239 & $(3.084,3.393)$ & 0.98 & 2.8 \\
\hline \multirow{8}{*}{$\begin{array}{c}\text { HPGP } \\
\text { (STERRAD } \mathbb{~} \\
100 \mathrm{~S})\end{array}$} & $3 \mathrm{M} \mathrm{1860S}$ & 1 & $\leq 0.49$ & 0.029 & $(0.026,0.032)$ & 0.99 & 4.3 \\
\hline & & 3 & $\leq 0.49$ & 0.504 & $(0.457,0.551)$ & 0.97 & 4.3 \\
\hline & & 5 & 4.00 & 9.271 & $(8.762,9.780)$ & 0.92 & 4.3 \\
\hline & & 10 & 11.11 & 14.274 & $(13.914,14.633)$ & 0.94 & 4.1 \\
\hline & $3 \mathrm{M} 8210$ & 1 & $\leq 0.49$ & 0.013 & $(0.007,0.019)$ & 0.94 & 3.0 \\
\hline & & 3 & $\leq 0.49$ & 3.576 & $(3.290,3.862)$ & 0.94 & 3.3 \\
\hline & & 5 & 4.00 & 6.494 & $(6.230,6.757)$ & 0.92 & 3.0 \\
\hline & & 10 & 11.11 & 6.914 & $(6.221,7.606)$ & 0.89 & 3.3 \\
\hline
\end{tabular}


medRxiv preprint doi: https://doi.org/10.1101/2020.05.14.20094821; this version posted May 18, 2020. The copyright holder for this preprint (which was not certified by peer review) is the author/funder, who has granted medRxiv a license to display the preprint in perpetuity.

It is made available under a CC-BY-NC 4.0 International license.

\begin{tabular}{|c|c|c|c|c|c|c|c|}
\hline & $3 \mathrm{M} 9210$ & $\begin{array}{c}1 \\
3 \\
5 \\
10 \\
\end{array}$ & $\begin{array}{c}\leq 0.49 \\
\leq 0.49 \\
14.29 \\
6.67 \\
\end{array}$ & $\begin{array}{c}0.027 \\
0.589 \\
1.607 \\
10.108 \\
\end{array}$ & $\begin{array}{c}(0.011,0.043) \\
(0.473,0.706) \\
(1.291,1.924) \\
(9.271,10.945)\end{array}$ & $\begin{array}{l}0.96 \\
0.84 \\
0.91 \\
0.95 \\
\end{array}$ & $\begin{array}{l}3.8 \\
3.8 \\
3.0 \\
4.1 \\
\end{array}$ \\
\hline \multirow{3}{*}{$\begin{array}{c}\text { HPV } \\
\text { (STERIS V- } \\
\text { Pro® maX) }\end{array}$} & $3 \mathrm{M} \mathrm{1860S}$ & $\begin{array}{c}1 \\
3 \\
5 \\
10\end{array}$ & $\begin{array}{c}\leq 0.49 \\
\leq 0.49 \\
0.51 \\
0.58 \\
\end{array}$ & $\begin{array}{l}0.118 \\
0.182 \\
0.849 \\
0.887 \\
\end{array}$ & $\begin{array}{l}(0.098,0.137) \\
(0.137,0.226) \\
(0.686,1.013) \\
(0.651,1.123)\end{array}$ & $\begin{array}{l}0.97 \\
0.94 \\
0.97 \\
0.93\end{array}$ & $\begin{array}{l}4.6 \\
4.8 \\
4.8 \\
4.3 \\
\end{array}$ \\
\hline & $3 \mathrm{M} 8210$ & $\begin{array}{c}1 \\
3 \\
5 \\
10 \\
\end{array}$ & $\begin{array}{c}\leq 0.49 \\
\leq 0.49 \\
0.57 \\
0.52 \\
\end{array}$ & $\begin{array}{l}0.109 \\
0.163 \\
0.277 \\
0.149 \\
\end{array}$ & $\begin{array}{l}(0.092,0.126) \\
(0.137,0.189) \\
(0.230,0.324) \\
(0.129,0.169)\end{array}$ & $\begin{array}{l}0.97 \\
0.93 \\
0.98 \\
0.99 \\
\end{array}$ & $\begin{array}{l}4.3 \\
3.8 \\
3.6 \\
3.8 \\
\end{array}$ \\
\hline & $3 \mathrm{M} 9210$ & $\begin{array}{c}1 \\
3 \\
5 \\
10 \\
\end{array}$ & $\begin{array}{l}\leq 0.49 \\
\leq 0.49 \\
\leq 0.49 \\
\leq 0.49 \\
\end{array}$ & $\begin{array}{l}0.098 \\
0.541 \\
0.424 \\
0.378 \\
\end{array}$ & $\begin{array}{l}(0.081,0.115) \\
(0.492,0.589) \\
(0.364,0.484) \\
(0.338,0.418) \\
\end{array}$ & $\begin{array}{l}0.98 \\
0.98 \\
0.96 \\
0.98 \\
\end{array}$ & $\begin{array}{l}4.6 \\
4.3 \\
4.3 \\
4.3 \\
\end{array}$ \\
\hline \multirow{3}{*}{ UVGI } & $3 \mathrm{M} 1860 \mathrm{~S}$ & $\begin{array}{l}1 \\
3 \\
5\end{array}$ & $\begin{array}{l}0.55 \\
0.81 \\
0.96\end{array}$ & $\begin{array}{l}0.064 \\
0.956 \\
1.121 \\
\end{array}$ & $\begin{array}{l}(0.054,0.074) \\
(0.639,1.273) \\
(1.003,1.238) \\
\end{array}$ & $\begin{array}{l}0.99 \\
0.94 \\
0.96 \\
\end{array}$ & $\begin{array}{l}4.6 \\
4.6 \\
4.6 \\
\end{array}$ \\
\hline & $3 \mathrm{M} 8210$ & $\begin{array}{l}1 \\
3 \\
5\end{array}$ & $\begin{array}{c}0.54 \\
\leq 0.49 \\
0.51\end{array}$ & $\begin{array}{l}0.097 \\
0.601 \\
0.258\end{array}$ & $\begin{array}{c}(0.061,0.134) \\
(0.477,0.726) \\
(0.186,0.330)\end{array}$ & $\begin{array}{l}0.97 \\
0.96 \\
0.96\end{array}$ & $\begin{array}{l}3.6 \\
3.8 \\
3.6\end{array}$ \\
\hline & $3 \mathrm{M} 9210$ & $\begin{array}{l}1 \\
3 \\
5\end{array}$ & $\begin{array}{l}\leq 0.49 \\
\leq 0.49 \\
\leq 0.49\end{array}$ & $\begin{array}{l}0.035 \\
0.083 \\
0.340 \\
\end{array}$ & $\begin{array}{c}(0.032,0.039) \\
(0.050,0.116) \\
(0.256,0.424)\end{array}$ & $\begin{array}{l}0.99 \\
0.96 \\
0.97 \\
\end{array}$ & $\begin{array}{l}3.0 \\
3.3 \\
4.6 \\
\end{array}$ \\
\hline
\end{tabular}

†The limit of detection for leakage was $0.49 \%$. Leakage for pristine N95 FFRs is reported as

494 mean values and their standard errors $(N=3)$.

$495 *$ The expectation values, confidence intervals and coefficients of determination are from power

496 regression performed on penetration measurements. 
medRxiv preprint doi: https://doi.org/10.1101/2020.05.14.20094821; this version posted May 18, 2020. The copyright holder for this preprint (which was not certified by peer review) is the author/funder, who has granted medRxiv a license to display the preprint in perpetuity.

It is made available under a CC-BY-NC 4.0 International license .

498 P.Z.C. designed the study, performed experiments, analyzed results and prepared visualizations.

499 A.N. and N.M. performed experiments. J.T.M., G.H.B., O.D.R. and F.X.G. supervised the

500 research. P.Z.C. and F.X.G. wrote the manuscript with review from all authors.

502 Acknowledgements

503 We would like to thank Jeffrey Sun, Febby Wong, Yang Ting Shek and Ayoob Ghalami at the

504 University of Toronto for assistance with fit testing and procurement; Ronald Hofmann and

505 Chengjin Wang at the University of Toronto for use of their fiber optic spectrometer and

506 discussions; and Stephenie Naugler and William Lau at St. Michael's Hospital for assistance

507 with reprocessing instrumentation. This research was supported by the Natural Sciences and

508 Engineering Research Council of Canada (NSERC), the University of Toronto COVID-19

509 Action Grant, the Hospital for Sick Children and Unity Health Toronto. P.Z.C. was supported by

510 the NSERC Vanier Scholarship. F.X.G. was partially supported by the NSERC Senior Industrial

511 Research Chair program.

512

$513 \quad$ Supplementary references

514 6. TEB-APR-STP-0059: Determination of particulate filter efficiency level for N95 series

515 filters Against solid particulates for non-powered, air-purifying respirators (revision: 3.2).

516 Cincinnati, OH: National Institute for Occupational Safety and Health, December 2019

517 (https://www.cdc.gov/niosh/npptl/stps/pdfs/TEB-APR-STP-0059-508.pdf). 
medRxiv preprint doi: https://doi.org/10.1101/2020.05.14.20094821; this version posted May 18, 2020. The copyright holder for this preprint (which was not certified by peer review) is the author/funder, who has granted medRxiv a license to display the preprint in perpetuity.

It is made available under a CC-BY-NC 4.0 International license .

518 7. Institute of Medicine (U.S). Committee on the fevelopment of reusable facemasks for use

519 during an influenza pandemic. reusability of facemasks during an influenza pandemic:

$520 \quad$ Facing the flu. Washington, D.C.: National Academies Press; 2006.

521 8. Tang JW, Noakes CJ, Nielsen PV, et al. Observing and quantifying airflows in the infection control of aerosol- and airborne-transmitted diseases: an overview of approaches.

J Hosp Infect 2011;77:213-22.

9. Reid JP, Mitchem L. Laser probing of single-aerosol droplet dynamics. Annu Rev Phys Chem 2006;57:245-71.

10. Maxey MR, Riley JJ. Equation of motion for a small rigid sphere in a nonuniform flow. Physics of Fluids 1983;26:883-9.

528 11. Nowak N, Kakade PP, Annapragada AV. Computational fluid dynamics simulation of airflow and aerosol deposition in human lungs. Ann Biomed Eng 2003;31:374-90.

530 12. Liu Y, Ning Z, Chen Y, et al. Aerodynamic analysis of SARS-CoV-2 in two Wuhan hospitals. Nature 2020 April 27 (Epub ahead of print).

532 13. Lu J, Gu J, Li K, et al. COVID-19 outbreak associated with air conditioning in restaurant, Guangzhou, China, 2020. Emerg Infect Dis 2020;26.

534 14. Li Q, Guan X, Wu P, et al. Early transmission dynamics in Wuhan, China, of novel 535 coronavirus-infected pneumonia. N Engl J Med 2020;382:1199-207.

536 15. Wang X, Pan Z, Cheng Z. Association between 2019-nCoV transmission and N95 respirator use. J Hosp Infect 2020;105:104-5.

538 16. Chen N, Zhou M, Dong X, et al. Epidemiological and clinical characteristics of 99 cases of 2019 novel coronavirus pneumonia in Wuhan, China: a descriptive study. Lancet 2020;395:507-13. 
medRxiv preprint doi: https://doi.org/10.1101/2020.05.14.20094821; this version posted May 18, 2020. The copyright holder for this preprint (which was not certified by peer review) is the author/funder, who has granted medRxiv a license to display the preprint in perpetuity.

It is made available under a CC-BY-NC 4.0 International license.

541 17. Bouvier NM, Palese P. The biology of influenza viruses. Vaccine 2008;26 Suppl 4:D49-

54253.

543 18. Judson SD, Munster VJ. Nosocomial transmission of emerging viruses via aerosol-

$544 \quad$ generating medical procedures. Viruses 2019;11.

545 19. Tellier R. Review of aerosol transmission of influenza A virus. Emerg Infect Dis

$546 \quad 2006 ; 12: 1657-62$.

547 20. Tang JW, Li Y, Eames I, Chan PK, Ridgway GL. Factors involved in the aerosol

548 transmission of infection and control of ventilation in healthcare premises. J Hosp Infect

$549 \quad 2006 ; 64: 100-14$

550 21. Kumar A, Kasloff SB, Leung A, et al. N95 mask decontamination using standard hospital

$551 \quad$ sterilization technologies. medRxiv 2020, April 20, 2020

552

(https://www.medrxiv.org/content/10.1101/2020.04.05.20049346v2).

553 22. Letter of emergency use authorization: STERIS sterilization systems. Silver Spring, MD:

$554 \quad$ U.S. Food and Drug Administration, April 9, 2020

$555 \quad$ (https://www.fda.gov/media/136843/download).

556 23. Letter of emergency use authorization: ASP STERRAD Sterilization Systems. Silver

557 Spring, MD: U.S. Food and Drug Administration, April 11, 2020

$558 \quad$ (https://www.fda.gov/media/136843/download).

559 24. Fischer R, Morris DH, van Doremalen N, et al. Assessment of N95 respirator

560 decontamination and re-use for SARS-CoV-2. medRxiv April 24, 2020

$561 \quad$ (https://www.medrxiv.org/content/10.1101/2020.04.11.20062018v2).

562 25. Wang T, Lien C, Liu S, Selveraj P. Effective heat inactivation of SARS-CoV-2. medRxiv

563 May 5, 2020 (https://www.medrxiv.org/content/10.1101/2020.04.29.20085498v1). 
medRxiv preprint doi: https://doi.org/10.1101/2020.05.14.20094821; this version posted May 18, 2020. The copyright holder for this preprint (which was not certified by peer review) is the author/funder, who has granted medRxiv a license to display the preprint in perpetuity.

It is made available under a CC-BY-NC 4.0 International license .

564 26. Liao L, Xiao W, Zhao M, et al. Can N95 respirators be reused after disinfection? How many times? ACS Nano 2020 May 5 (Epub ahead of print).

27. Mills D, Harnish DA, Lawrence C, Sandoval-Powers M, Heimbuch BK. Ultraviolet germicidal irradiation of influenza-contaminated N95 filtering facepiece respirators. Am J

28. Jenum J. Penetration of ambient aerosols through respirator faceseal leaks (Application Note ITI-055), 1995 (https://www.tsi.com/getmedia/d4de5465-b3ed-4ab1-bc3acb6b5c77c50b/Penetration-of-Ambient-Aerosols-App-Note-ITI-055-US?ext=.pdf).

29. Brosseau LM. Fit testing respirators for public health medical emergencies. J Occup Environ Hyg 2010;7:628-32.

30. Roberge RJ, Monaghan WD, Palmiero AJ, Shaffer R, Bergman MS. Infrared imaging for leak detection of N95 filtering facepiece respirators: a pilot study. Am J Ind Med

31. Grinshpun SA, Haruta H, Eninger RM, Reponen T, McKay RT, Lee SA. Performance of an N95 filtering facepiece particulate respirator and a surgical mask during human breathing: two pathways for particle penetration. J Occup Environ Hyg 2009;6:593-603.

32. AIA Academy of Architecture for Health., Facilities Guidelines Institute., United States. Department of Health and Human Services. Guidelines for design and construction of hospital and health care facilities. Washington, D.C.: The American Institute of Architects;

584 33. ASTM F2299 / F2299M-03(2017), Standard test method for determining the initial efficiency of materials used in medical face masks to penetration by particulates using 
latex spheres. West Conshohocken, PA: ASTM International, 2017

(https://www.astm.org/Standards/F2299.htm).

588 34. ASTM F2100-19, Standard specification for performance of materials used in medical face masks. West Conshohocken, PA: ASTM International, 2019 (https://www.astm.org/Standards/F2100.htm).

591 35. Mahdavi A, Haghighat F, Bahloul A, Brochot C, Ostiguy C. Particle loading time and 592 humidity effects on the efficiency of an N95 filtering facepiece respirator model under constant and inhalation cyclic flows. Ann Occup Hyg 2015;59:629-40.

594 36. Wellek S. Testing statistical hypotheses of equivalence and noninferiority. 2nd ed. Boca Raton: CRC Press; 2010.

596 37. Łowkis B, Motyl E. Electret properties of polypropylene fabrics. Journal of Electrostatics 2001;51-52:232-8. 